\title{
A NEM SZUICIDÁLIS ÖNSÉRTÉS ÉS MOTIVÁCIÓJÁNAK MÉRÉSE SERDÜLŐKNÉL: AZ ÁLLÍTÁSOK AZ ÖNSÉRTÉS KAPCSÁN KÉRDÔIIV (ISAS-HU) MAGYAR ADAPTÁCIÓJA
}

\author{
REINHARDT MELINDA ${ }^{1,2 *}-$ KÖKÖNYEI GYÖNGYI ${ }^{1,3,4}-$ \\ DRUBINA BOGLÁRKA ${ }^{5,1,6}$ - URBÁN RÓBERT ${ }^{1}$
}

\author{
${ }^{1}$ ELTE Eötvös Loránd Tudományegyetem Pszichológiai Intézet, Budapest, Magyarország \\ ${ }^{2}$ Zuglói Egészségügyi Szolgálat, Gyermek- és Serdülốpszichiátria, Budapest, Magyarország \\ ${ }^{3}$ SE-NAP 2 Genetikai Agyi Képalkotó Migrén Kutatócsoport, MTA, SE, Budapest, Magyarország \\ ${ }^{4}$ Semmelweis Egyetem, Gyógyszerhatástani Intézet, Budapest, Magyarország \\ ${ }^{5}$ ELTE PPK Pszichológiai Doktori Iskola, Budapest, Magyarország \\ ${ }^{6}$ Területi Gyermekvédelmi Központ és Fôvárosi Gyermekvédelmi Szakszolgálat, \\ Szakértối Bizottság, Budapest, Magyarország \\ E-mail: reinhardt.melinda@ppk.elte.hu
}

Benyújtva: 2021. január 11. - Elfogadva: 2021. május 27.

\begin{abstract}
Háttér és célkitûzések: A nem öngyilkossági szándékkal végrehajtott szándékos önsértés (pl. a testfelszín direkt megvágása, megütése) élettartam-prevalenciáját a különbözố kutatások normatív kamaszpopulációkban 18 és $40 \%$ közé teszik. Kevés olyan kérdôiv van azonban, mely az önsértést részletesen tárja fel. Kutatásunk célja egy összetett önsértés kérdốv, az Állitások az Önsértés Kapcsán Kérdốiv (ISAS-HU) bevezetése volt a magyar tesztállományba.

Módszer: 1015 középiskolás kamasz (66,1\%; $N$ = 671 lány; átlagéletkor 16,81 év; szórás = 1,42) töltötte ki a kérdöivcsomagot, mely az önsértés komplex felmérése mellett érzelemszabályozási nehézségekre és pszichés betegségtünetekre kérdezett rá.

Eredmények: A vizsgált serdülók 58,8\%-a $(N=597)$ sohasem folytatott élete során önsértést, míg 41,2\%-uk $(N=418)$ arról számolt be, hogy végzett már legalább egyszer valamilyen önsértô cselekedetet. A teljes minta 31,7\%-a (N=322) mindezt az elmúlt hónapban tette. A lányok másfélszer nagyobb eséllyel válnak önsértốvé, mint a fuúk, s a sohasem önsértók jellemezhetốk a legjobb pszichés egészségmutatókkal. Tanulmányunkban az önsértéshez kapcsolódó attitüdinális komponensek leíró adatait is közöljük. A kérdôí második egységén, az önsértés hátterében álló lehetséges okok tételein elvégzett, azok kereszttöltéseit is megengedô megerösítö faktorelemzés (Exploratory Structural Equation Modeling) a skála eredeti kétfaktoros
\end{abstract}

* levelezô szerzô; ORCID: https://orcid.org/0000-0001-7010-5623

(C) 2021 A szerzố(k) 
szerkezetét igazolta. Az önsértés hátterében egy markáns intraperszonális és egy interperszonális motívumkör rajzolódott ki, kiváló megbizhatósági mutatókkal. Az önsértố lányok almintáján elvégzett validációs elemzések az elvártakat igazolták: az intraperszonális okok miatt elkövetett önsértés rosszabb pszichés állapottal és kifejezettebb érzelemszabályozási nehézségekkel társult. A repetitív önsértôk a „kipróbálókhoz” képest pedig inkább intraperszonális okok miatt folytatnak önsértést.

Következtetések: Az ISAS-HU egy pszichometriailag jól müködố, a nem szuicidális önsértést számos szempontból könnyen és gyorsan felméró komplex méröeszköz.

Kulcsszavak: nem öngyilkossági szándékkal történô önsértés, Állitások az Önsértés Kapcsán Kérdốiv, kérdôiv-adaptáció, pszichometria, serdülók

\section{BEVEZETÉS}

A nem öngyilkossági szándékkal elkövetett önsértés (non-suicidal self-injury; NSSI) a saját test akaratlagos, de nem öngyilkossági szándékkal végrehajtott megsértését jelenti (International Society for the Study of Self-Injury, 2018). Ilyen lehet például a testfelszín megvágása, megütése, megkarmolása, megharapása és megégetése, de idesorolják a sebgyógyulás szándékos megakadályozását vagy veszélyes anyag lenyelését is szuicid szándék nélkül (Klonsky és Glenn, 2009). Annak ellenére, hogy több vizsgálat (pl. Andover és Gibb, 2010) az NSSI-t az öngyilkossági szándék és viselkedés rizikófaktoraként azonosította, fontos megkülönböztetnünk azoktól: az NSSI-ben az öndestruktív viselkedéshez nem kapcsolódik öngyilkossági szándék és magatartás, bár párhuzamosan jelen lehet azzal (Klonsky, Victor és Shaffer, 2014).

\section{A nem öngyilkossági szándékkal történő önsértés serdülók körében}

A kutatások konzisztensek abban a tekintetben, hogy az NSSI-cselekedetek a leggyakrabban serdülőkorban fordulnak elő (Brown és Plener, 2017). Egy több mint 50 vizsgálatot összefoglaló szisztematikus áttekintés az NSSI élettartam-prevalenciájának átlagát 18\%-ban állapította meg kamaszpopulációkban (Muehlenkamp, Claes, Havertape és Plener 2012). A tanulmány azonban arra is felhívja a figyelmet, hogy a különbözô vizsgálatok becslésében jelentôs eltérés lehet azok módszertani különbségei miatt. Amíg az eldöntendô kérdéstípuson alapuló felmérések átlagosan 12,5\%-os élettartam-gyakoriságot jeleznek, addig a különbözô önsértô viselkedéseket felsoroló és azok jellemzôit részletesebben feltáró listák átlagosan majdnem kétszeres élettartam-prevalenciát (23,6\%) azonosítanak (Muehlenkamp és mtsai, 2012). Több, serdülók körében végzett kutatásban nem ritka a 40\%-ot közelítô elófordulási gyakoriság sem (Brunner és mtsai, 2014; Jacobson és Gould, 2007), ami arra is utalhat, hogy az egyes nemzeti minták között különbség lehet a nem szuicidális önsértés elófordulási gyakoriságában. Problémát jelent továbbá az összehasonlításban az is, hogy a legtöbb kutatás csupán életprevalencia-értéket közöl az önsértés kapcsán, pontprevalenciát nem adnak meg. Ehhez kapcsolódik, hogy a felmérések gyakran nem figyelnek arra, hogy a felmért önsértés fennáll-e aktuálisan, vagy csak a múltban volt jelen. Azok az önsértéskutatások és -kérdôívek, melyek erre a szempontra is figyelnek, általában az egy hónapon belül 
önsértést végzôket tekintik jelenleg önsértôknek (Claes és Vandereycken, 2007). Egy friss haza felmérés szerint az NSSI élettartam-prevalenciája nem klinikai serdüló mintában 23,6\% volt (Horváth és mtsai, 2020). Ebben a kutatásban önsértônek azt tekintették, aki a Deliberate Self-Harm Inventory (DSHI; Gratz, 2001) kérdôív alapján a felsorolt 16 önsértô viselkedés bármelyikére igen választ adott. Ki kell emelnünk azt a nemzetközi szakirodalomban egyértelmúen megjelenô trendet is, amely az NSSI prevalenciájának radikális emelkedését jelzi az elmúlt egy évtized során. Wester, Trepal és King (2018) például elsôéves amerikai egyetemisták körében mutatták ki, hogy 2008 és 2015 között az NSSI élettartam-prevalenciája 16\%-ról 45\%-ra nôtt.

Az önsértô viselkedés tekintetében fontos figyelembe vennünk annak gyakoriságát is. A serdülő́k egy része ugyanis csak „kipróbálja” az NSSI valamely formáját, de azt követően nem folytatja (Swannell, Martin, Page, Hasking és John, 2014). A DSM-5 (Diagnostic and Statistical Manual of Mental Disorders 5th edition; American Psychiatric Association, 2013) diagnosztikai kézikönyve a további kutatásokat igénylô állapotok fejezetében megfontolásra ajánlja a nem szuicidális önsértés zavart (non-suicidal self-injury disorder, NSSID). Az NSSID egyik fố kritériuma a repetitív önsértés. Ennek alapján a zavarszintú önsértés akkor lenne kódolható, ha a személy az elmúlt év során legalább öt alkalommal végzett valamilyen NSSI-cselekedetet. Zetterqvist (2015) áttekintố tanulmánya szerint az így meghatározott önsértés gyermek és serdülô nem klinikai mintákban 1,5\% körül mozgott.

Fontos demográfiai tény, hogy a kutatások konzisztensen a serdülő lányok önsértésre való magasabb kockázatát jelzik. Különösen igaz ez a klinikai populációra, de normatív mintákban is rendre kimutatják ezt az összefüggést (Bresin és Schoenleber, 2015). Nemi különbséget mutattak ki továbbá az alkalmazott önsértési módokban is. Nem klinikai serdülô mintában a lányok a leggyakrabban vágásról számoltak be, míg a fiúk önmaguk megütéséról vagy arról, hogy direkt beütötték valamelyik testrészüket (Barrocas, Hankin, Young és Abela, 2012).

\section{A nem szuicidális önsértés rizikótényezői és összefüggései más pszichológiai változókkal}

Az elmúlt évtizedben az NSSI rizikófaktorainak feltárása az önsértéskutatások középpontjába került. A megfelelô társas készségek hiánya és az alacsony önkompetencia az önsértés legrelevánsabb rizikótényezôinek bizonyultak (Baetens, Claes, Muehlenkamp, Grietens és Onghena, 2012). Ennek háttere, hogy a szociális alkalmazkodás problémái gátolják az adekvát társas válaszadást és problémamegoldást (Nock és Mendes, 2008). A figyelmi nehézségek, valamint a múltbeli és jelenbeli negatív életesemények szintén megnövelhetik az NSSI kialakulásának valószínúségét (Liu, Frazier, Cataldo, Simon, Spirito és Prinstein, 2014). A fájdalomanalgézia pedig önmagában is rizikófaktornak bizonyult az önsértés tekintetében (Glenn, Michel, Franklin, Hooley és Nock, 2014). Egy húsz tanulmányt összefoglaló metaanalízis az NSSI legfontosabb rizikófaktoraiként pedig a korábbi NSSI-cselekedeteket, a B-klaszteres személyiségzavar-tüneteket (pl. szélsôséges hangulatingadozás, impulzuskontroll-zavarok, kötôdési nehézségek) és a reménytelenség érzését azonosította (Fox és mtsai, 2015). Ugyanakkor a metaanalízisben arra is rámutattak, hogy ezeket az összefüggéseket a minta 
jellege, az életkor és az önsértést becslố mérôeszköz jelentôsen meghatározta. Klinikai (vs. normatív) és felnôtt mintákban (vs. serdülők), valamint folytonos skálán alapuló mérésekben (vs. igen-nem típusúak) ugyanis a fenti rizikófaktorok szignifikánsan erôteljesebb bejóslói voltak az NSSI-nek (Fox és mtsai, 2015).

Az NSSI-cselekedetekkel kapcsolatban számos diszfunkcionális érzelemszabályozó stratégiát sikerült azonosítani. Ezek közül az elkerülésfókuszú érzelemregulációs mechanizmusok emelkednek ki, így a disszociáció (Batey, May és Andrade, 2010) és a negatív élmények elkerülésére irányuló kognitív torzítás, a tapasztalati elkerülés (experiential avoidance, EA) (Brereton és McGlinchey, 2019). Mindkét maladaptív érzelemszabályozó stratégia, ahogyan maga az önsértés is, időszakosan abban segítheti a személyt, hogy nem kívánt érzelmeinek átélését elkerülje (Chapman, Gratz és Brown, 2006). Az NSSI kurrens magyarázómodelljei közül több is (pl. a Tapasztalati Elkerülés Modell; Experiential Avoidance Model [EAM], Chapman és mtsai, 2006) az NSSI-dinamika központi elemének tekinti a negatív tapasztalatok (érzelmi állapotok, gondolatok, emlékek) elkerülésének tendenciáját (bóvebben ld. Brereton és McGlinchey [2019] szisztematikus irodalmi áttekintését). A Tapasztalati Elkerülés Modell szerint az alacsony distressztolerancia és az érzelemregulációs deficitek olyan erôs intenzitású érzelmekhez vezethetnek, amelyek azért aktiválnak önsértést, hogy annak segítségével a személy elkerülhesse a fájdalmas érzelmi élményeket (Chapman és mtsai, 2006). Brereton és McGlinchey (2019) arra is felhívja a figyelmet, hogy csupán két olyan tanulmányt találtak, amely serdülook körében tesztelte a tapasztalati elkerülés és az NSSI kapcsolatát.

Az NSSI-viselkedéssel gyakran társulnak továbbá hangulati és szorongásos tünetek, illetve zavarok, sốt a nem szuicidális önsértés mint transzdiagnosztikus jelenség a mentális zavarok teljes spektrumában elôfordulhat (Bentley, Cassiello-Robbins, Vittorio, Sauer-Zavala és Barlow, 2015).

\section{A nem szuicidális önsértés felmérése}

A fentiek is rámutatnak arra, hogy a nem öngyilkossági szándékkal történô önsértés egy összetett jelenség. Ezzel szoros összefüggésben a felmérésében is érvényesülnie kell ennek a komplexitásnak. A dichotóm formájú (végzett-e önsértést vagy sem) becsléseket meghaladva érdemes az NSSI-cselekedeteket részletesebben feltárni. Az elmúlt évtizedekben több mérôeszközt is kifejlesztettek az NSSI-viselkedés mérésére (ld. Sansone és Sansone [2010] összefoglalóját). Ezek közül azonban számos csak az önsértô viselkedés fajtáit, megjelenését és előfordulási gyakoriságát méri fel (pl. Deliberate Self-Harm Inventory, DSHI; Gratz, 2001). Mások rendkívül hosszúak (pl. Self-Harm Behavior Survey; Favazza, 1986), vagy az öngyilkosságra is rákérdeznek (pl. DSHI; Gratz, 2001). Kevés olyan kérdôív van, amely a jelenség átfogó felmérését adja. Hazánkban eddig egy összetett, a nem szuicidális önsértés feltérképezésére alkalmas eszközt vezettek be a teszthasználatba, a Self-Injury Questionnaire-Treatment Related (SIQ-TR, Claes és Vandereycken, 2007; magyarul: Kezelésközpontú Önsértés Kérdôív; Reinhardt, Drubina, Horváth és Kökönyei, 2020) elnevezésû mérôeszközt. Ez azonban 
terjedelmes, s leginkább a klinikai gyakorlatban alkalmazható kérdôív. Tanulmányunk fố célja ezért egy összetett, normatív populációkban is alkalmazható NSSI-mérôeszköz bevezetése volt a magyar tesztállományba.

\section{Az eredeti kérdőiv bemutatása}

\section{Az Inventory of Statements About Self-Injury (ISAS; Klonsky és Glenn, 2009) felépitése}

A mérôeszköz, mely megtalálható a Függelékben, két nagy részből áll: az (I) elsô rész (Behaviors) a nem szuicidális önsértés leíró adataira, míg a (II) második rész (Functions) az annak hátterében meghúzódó okokra kérdez rá. A kérdôivet bevezetố instrukció tisztán definiálja, mit tekintünk önsértố viselkedésnek: kiemeli annak szándékos és a saját személyre (testre) irányuló voltát, valamint azt, hogy az ilyen cselekedetek hátterében nem áll öngyilkossági késztetés.

Az (I) elsố egység elôször 12 önsértési formát sorol fel (pl. megvágtad magad, megharaptad magad, nagyon erôsen/mélyen megkarmoltad magad, beütötted vagy megütötted magad, megakadályoztad a sebeid gyógyulását). Lehetôség van arra is, hogy egy 13., addig fel nem sorolt önsértési módot is beírjon a személy. A kitöltônek (a) azt kell megbecsülnie, hogy élete folyamán körülbelül hányszor sértette meg magát a felsorolt módokon. Amennyiben sohasem, akkor 0-át kell beírnia. A kérdőív kitöltését azok folytatják, akik valamilyen módon végeztek életük során önsértô cselekvést. Ôk a következố területeket fedik fel az önsértés kapcsán: (b) megjelölik a számukra legjellemzőbb, leggyakoribb önsértési módot, (c) megadják, hogy hány évesen végeztek elôször önsértést, és mikor önsértettek legutoljára, (d) tapasztaltak-e fizikai fájdalmat önsértés közben, (e) egyedül voltak-e önsértés közben, (f) általában mennyi idô telik el aközött, hogy késztetést éreznek az önsértésre, és azt meg is teszik, illetve (g) szerették volna-e/szeretnék-e abbahagyni az önsértô viselkedést.

A (II) második egység 39 tétellel az önsértés hátterében meghúzódó lehetséges okokat tárja fel a személyre jellemzôen. A kitöltô háromfokú skálán $(0=$ nem jellemzó, 1 = valamennyire jellemzô, 2 = nagyon jellemzố) ítéli meg, hogy az adott állítás mennyire vonatkoztatható rá, amikor önsértést végez („Amikor önsértést végzek, akkor azáltal...”). Klonksy és Glenn (2009) az önsértés 13 lehetséges okát azonosította: (1) Érzelemszabályozó funkció (1., 14., 27. tétel); (2) Személyközi határok szabályozása (2., 15., 28. tétel); (3) Önbüntetés (3., 16., 29. tétel); (4) Gondoskodás önmagáról (4., 17., 30. tétel); (5) Disszociáció megszüntetése/érzések generálása (5., 18., 31. tétel); (6) Öngyilkossági gondolatok megelôzése (6., 19., 32. tétel); (7) Szenzoros élménykeresés (7., 20., 33. tétel); (8) Kötốdés a kortársakhoz (8., 21., 34. tétel); (9) Interperszonális figyelem kiváltása (9., 22., 35. tétel); (10) Szívósság kifejezése (10., 23., 36. tétel); (11) Distressz jelzése (11., 24., 37. tétel); (12) Bosszú kifejezése (12., 25., 38. tétel) és (13) Autonómia kifejezése (13., 26., 39. tétel). Mind a 13 okra 3-3 tétel töltôdik, s mindegyiken minimum 0 (nem jellemzô az adott ok az önsértés hátterében), maximum 6 pont (az adott motiváció kifejezetten jelen van az önsértés során) szerezhetô. Washburn és munkatársai (2012) kialakították az ISAS második részének rövid változatát. Ebben a 13 okot 26 tétel méri fel, mindegyik funkciót a hosszú változat két-két 
legjellemzőbb tétele fedi le, így funkciónként minimum 0, maximum 4 pont szerezhetô. A Függelék végén bemutatjuk a rövid változat tételeit és kiértékelését is.

A kérdôív két opcionálisan megválaszolható nyitott kérdéssel zárul, melyek szabad kifejtést biztosítanak azzal kapcsolatban, hogy van-e olyan ok a személy önsértése hátterében, amely nem szerepelt a kérdôívben, illetve mit gondol, van-e olyan motiváció az önsértés hátterében, amelyet a kérdôív nem sorolt fel, de jellemzô lehet, vagy elôfordulhat.

\section{Az Inventory of Statements About Self-Injury (ISAS; Klonsky és Glenn, 2009) pszichometriai jellemző $i$}

Az ISAS elsô egységénél előfordulásra (pl. mikor végzett legutoljára önsértést) és gyakoriságra (pl. hányszor vágta meg magát szándékosan a személy életében) vonatkozó adatokat, továbbá dichotóm (igen vagy nem) vagy diszkrét (igen, néha, nem) változókkal jellemezhetô önsértés-demográfiai adatokat kapunk. Ezek lehetôséget adnak a különbözó nemzetközi vagy hazai kutatásokban az összehasonlításra.

A második kérdôívegységnél elemezhetjük a 13 funkción elért átlagokat, így az önsértés hátterében álló legjellemzőbb motívumokat. Klonsky és Glenn (2009) a 13 okot feltáró faktorelemzéssel (Exploratory Factor Analysis; EFA) két tágabb funkciókörbe rendezték: egy intraperszonális és egy interperszonális faktort azonosítottak. Ez a két nagy faktor harmonikusan megerôsíti Nock és Prinstein (2004) Négy Funkció Modelljét (Four Function Model, FFM), mely a nem szuicidális önsértés motivációit teoretikusan kategorizálja. Nock és Prinstein (2004) felosztásában az önsértô cselekedetek (1) csökkentik a negatív érzéseket, vagy (2) pozitív, vágyott érzelmi állapotokat generalizálnak. Elôbbit intraperszonális negatív megerôsítô, utóbbit intraperszonális pozitív megerôsítő funkciónak nevezik. Az önsértô viselkedés továbbá szociális tapasztalatokat is (3) csökkenthet vagy éppen (4) indukálhat (pl. eltávolít másoktól, vagy közös tapasztalatot képez a kortársakkal). Elóbbit interperszonális negatív, utóbbit interperszonális pozitív megerôsítésként címkézik. Az önsértés tehát történhet intraperszonális (érzelmek kezelése) és interperszonális (társas hatások kezelése) motívumok mentén. Az intraperszonális motívumokat gyakrabban azonosítják az önsértés hátterében álló tényezókként (Brackman és Andover, 2017; Taylor, Jomar, Dhingra, Forrester és Shahmalak, 2018). Ezek közül is különösen az érzelemszabályozó és az önbüntetô tendenciákat emelik ki a kutatások (Klonsky, 2007; Kortge, Mead és Tennant, 2013).

Klonsky és Glenn (2009) faktorelemzése intraperszonális motívumként írja le az Érzelemszabályozó, a Disszociáció megszüntetése, az Öngyilkossági gondolatok megelôzése, a Distressz jelzése és az Önbüntetés skálákat. Az interperszonális motívumkörbe pedig a következó nyolc faktor került az elemzés szerint: Autonómia kifejezése, Személyközi határok szabályozása, Interperszonális figyelem kiváltása, Kötôdés a kortársakhoz, Bosszú kifejezése, Gondoskodás önmagáról, Szenzoros élménykeresés, valamint a Szívósság kifejezése. A faktorszerkezetben egyetlen bizonytalanság mutatkozott. Az Önmagáról való gondoskodás skála közel azonos - közepes - mértékben töltốdött mind az intra-, mind az interperszonális faktorokra. Másrészt a skála tartalmilag jobban kötôdik az intraperszonális okokhoz, hiszen arra utal, hogy a személy 
az önsértéssel létrehoz egy fizikai sebet, melyrôl gondoskodhat ahelyett, hogy a saját érzelmi distresszét élné meg.

A mérôeszköz bevezetô tanulmányában a két nagy faktor kiváló belsô konzisztenciával bírt (Cronbach- $\alpha=0,80$ az intraperszonális és Cronbach- $\alpha=0,88$ az interperszonális faktor esetében), ahogyan érvényessége is megerôsítést nyert. A konvergens validitási adatok szerint mind az intra-, mind az interperszonális motívumok pozitív kapcsolatban álltak az öngyilkossági gondolatokkal, a depresszív tünetekkel és az érzelmileg labilis személyiségzavarral egyetemista mintában. Az intraperszonális motívumok pedig erôteljesebben asszociálódtak a depresszív tünetekkel és az öngyilkossági gondolatokkal, mint az interperszonális funkciók (Klonsky és Glenn, 2009).

A kiváló validitás- és reliabilitásadatoknak köszönhetôen a kérdôív hamar elterjedt az utóbbi évtized önsértéskutatásaiban. Minden további kutatás megerôsítette a két felsôbbrendú funkciófaktort. Például egy széles életkori övezetet felölelô klinikai mintán alapuló (Klonksy, Glenn, Styer, Olino és Washburn, 2015) és egy angol nyelvú országokat (USA, Nagy-Britannia, Kanada, Ausztrália) bevonó nagy mintás kutatás is (Kortge és mtsai, 2013). Török (Bildik, Somer, Kabukcu Basay, Basay és Ozbaran, 2013), koreai (Kim, Kim és Hur, 2019) és spanyol (Pérez, García-Alandete, Cañabate és Marco, 2020) kutatások megerôsítő faktorelemzéssel (Confirmatory Factor Analysis, CFA) is alátámasztották, hogy a motívumok két faktorba rendezôdtek. Az Önmagáról való gondoskodás skála továbbra is bizonytalanságot mutatott: bizonyos kutatásokban az intraperszonális (pl. Kortge és mtsai, 2013), más kutatásokban az interperszonális (pl. Bildik és mtsai, 2013) faktorhoz kötődött. Megjegyezzük azonban, hogy a török középiskolás mintában kimutatott két nagy látens faktor olyan magasan korrelált egymással ( $r=0,92$; Bildik és mtsai, 2013), hogy az felveti egy specifikus motivációkat összefogó, általános funkciófaktor jelenlétét az önsértés hátterében. Kiemeljük, hogy az önsértés hátterében álló okok nemi különbségeit eddig rendkívül kevés kutatás vizsgálta. Ezek szerint a lányok önsértésének hátterében jóval gyakoribb az önbüntetô tendencia és valamilyen nem kívánt érzelmi állapot elkerülése, mint a fiúk esetében (Rodham, Hawton és Evans, 2004; Scoliers és mtsai, 2009). Scoliers és munkatársai (2009) ehhez még hozzáteszik, hogy a serdülô lányok több okot sorolnak fel az önsértésbe való bevonódás kapcsán, mint a fiúk, valamint gyakrabban említik önsértésük háttereként, hogy mennyire reménytelennek érzik magukat. Az ISAS funkcióskála nemi invarianciáját pedig még nem tesztelték.

\section{Jelen vizsgálat célkitúzései}

Célunk az ISAS magyar változatát, az Állítások az Önsértés Kapcsán Kérdôívet (ISAS-HU) - annak pszichometriai tesztelésével - bevezetni a hazai tesztállományba. Az adaptációs folyamat részeként magyar serdülook mintáján a kérdốiv leíró adatait is közöljük. Ez hiánypótló a hazai szakirodalomban: nagy, normatív serdülô mintán elôször adunk részletes - az NSSI számos aspektusára kiterjedô - jellemzést a középiskolás korosztály nem szuicidális önsértéssel kapcsolatos adatairól. Az önsértéssel kapcsolatban ugyanis nem pusztán az egyes önsértési módok prevalenciaértékeit, hanem 
az önsértéshez kapcsolódó attitüdinális és motivációs komponensek leíró adatait is közöljük. A magas mintaelemszám lehetôvé teszi, hogy a kérdốív-validáció keretében elvégezzük az ISAS II. részének megerôsítô faktorelemzését is. Ennek során versengô modelleket tesztelünk és választjuk ki a pszichometriailag legjobban illeszkedő faktorstruktúrát. A kérdôív második felének (funkcióskála) faktorszerkezete mellett annak nemi invarianciáját, reliabilitását és validitását is tesztelni kívánjuk. Vizsgáljuk továbbá az életük folyamán (1) sohasem, a (2) valaha és a (3) jelenleg önsértố kamaszok mentális egészségszintjében (internalizáló és externalizáló tünetek), valamint általános és specifikus érzelemszabályozó stratégiáiban (önkritikus rumináció és tapasztalati elkerülés) megmutatkozó különbségeket. Hipotézisünk szerint azok a serdülók, akik életük során sohasem végeztek önsértést, jobb érzelemregulációs színvonallal és kevesebb mentális betegségtünettel jellemezhetôk a korábban vagy aktuálisan önsértôkhöz képest.

\section{MÓDSZER}

\section{Minta}

A vizsgálatban való részvételt 1059 középiskolás tanuló vállalta. Hiányos kitöltés miatt 44 kitöltố adatát zártuk ki, a végsô mintát így 1015 fô alkotta. Közülük 66,1\% $(\mathrm{N}=671)$ lány volt, $33,7 \%$ pedig fiú $(\mathrm{N}=342)$, ketten $(0,2 \%)$ nem adták meg a nemüket. 27\%-uk $(\mathrm{N}=274)$ 9. osztályos, 25,2\% ( $=256) 10$. osztályos, 24,2\% ( $\mathrm{N}=246)$ 11. évfolyamos, míg 23\%-uk $(\mathrm{N}=233) 12$. osztályos tanuló volt. Hatan $(0,6 \%)$ nem jelölték meg évfolyamukat. A 14 és 20 év közötti kitöltôk átlagéletkora 16,81 év volt (szórás = 1,42). A minta nagy része városban él (25\% Budapesten, $44 \%$ más városban), közel egyharmada ( $31 \%$ ) pedig községben. A lányok (á = 16,84; szórás = 1,40) és a fiúk (á = 16,75; szórás $=1,45$ ) között nem volt eltérés életkori átlagukat tekintve $[\mathrm{t}(1005)=1,05 ; \mathrm{p}=0,295 ; \mathrm{d}=0,06]$. Nem mutatkozott továbbá nemi különbség a lakóhelytípus megoszlását illetôen sem $\left[\chi^{2}(2)=5,81 ; p=0,055 ; \varphi=0,08\right]$. A szülốk legnagyobb arányban felsôfokú (apák 44\%-a; anyák 51\%-a) vagy középfokú végzettséggel rendelkeztek (apák 24\%-a; anyák 30\%-a).

\section{Eszközök}

A fejezetben a demográfiai kérdések (pl. nem, kor, évfolyam, lakóhely típusa, szülôk iskolai végzettsége) mellett az elemzésekben szereplô, a validáció szempontjából kiemelt öt mérôeszközt mutatjuk be.

\section{Az Állitások az Önsértés Kapcsán Kérdôiv magyar nyelvú változatának elkészitése}

A kérdôív eredeti, angol nyelvú változatát (Inventory of Statements About SelfInjury; ISAS) és annak kiértékelését E. David Klonsky, a kérdôív kialakítója bocsátotta Reinhardt Melinda rendelkezésére a mérôeszköz magyar adaptációja céljából. A ma- 
gyar fordítást Reinhardt Melinda és Kökönyei Gyöngyi végezték 2018-ban. A fordítási folyamat visszafordítással is kiegészült. A visszafordított változatot Klonsky professzor vetette össze az eredetivel, észrevételei alapján készült el a végsố magyar nyelvú kérdôív. A magyar változat az Állítások az Önsértés Kapcsán Kérdôív (ISAS-HU) elnevezést kapta, amely szerkezetében és tartalmában teljesen paralel az eredeti (ISAS) kérdôível. A mérốeszköz részletes leírása az elméleti bevezetôben, magyar nyelvú változata pedig a Függelékben található meg. Kutatási célokra az eredeti és a magyar változat egyaránt szabadon felhasználható.

\section{Magányosság felmérése}

A magány érzését egy általunk kialakított kérdéssel mértük fel: Szoktad-e magányosnak érezni magad? A kérdésre négyfokozatú skálán jelölte be válaszát a kitöltô ( 1 = igen, nagyon gyakran és $4=$ nem, soha).

\section{Képességek és Nehézségek Kérdôiv}

A mentális betegségtüneteket a Képességek és Nehézségek Kérdôível (Strength and Difficulties Questionnaire; SDQ; Goodman, Meltzer és Bailey, 1998) összegeztük. A 25 tételes önbeszámolós kérdôív mind az internalizáló, mind az externalizáló pszichés problémákat azonosítja. Öt skála építi fel: (1) érzelmi tünetek; (2) viselkedéses problémák; (3) hiperaktivitás, figyelmi problémák; (4) kortárskapcsolati problémák és (5) proszociális viselkedés. Az elsố négy skála összpontszámából egy összproblémapontszám is számítható. Az internalizáló tünetkör az (1) érzelmi tünetek és a (4) kortárskapcsolati problémák összeadásából, míg az externalizáló tünetek a (2) viselkedéses és a (3) hiperaktivitás, figyelmi problémák összegzésébôl adódnak. A kitöltôk 0-tól (nem igaz) 2-ig (határozottan igaz) tudják a tételeket értékelni. Az (1)-(4) skála esetén a magasabb pontszám súlyosabb problémákat jelez, míg a (5) proszocialitás skála esetében a magasabb pont több proszociális aktivitást jelez. Vizsgálatunkban az összproblémapontszámmal, az internalizáló és az externalizáló tünet, valamint a proszocialitás skálával dolgoztunk. Az eredeti vizsgálatban az összprobléma skála belsố megbízhatósága (Cronbach- $\alpha=0,82$ ) kiválónak bizonyult, míg a proszocialitás skála reliabilitása (Cronbach- $\alpha=0,65$ ) csak közelítette az elfogadható értéket (Goodman és mtsai, 1998). Saját vizsgálatunkban a reliabilitásértékek az összprobléma (Cronbach- $\alpha=0,75)$ és az internalizáló tünetek (Cronbach- $\alpha=0,75)$ skálák esetében jónak bizonyultak, míg az externalizáló tünetek (Cronbach- $\alpha=0,64)$ és a proszocialitás skála (Cronbach- $\alpha=0,67)$ esetében csak közelítették az elfogadható értéket. A kérdôív jól elkülöníti a tünetszint alapján a normatív és a klinikai csoportokat (Goodman és mtsai, 1998). Magyar adaptációja Turi, Tóth és Gervai (2011) munkája.

\section{Érzelemszabályozási Nehézségek Kérdôiv rövid változat (DERS-16)}

Munkánkban az érzelemszabályozás területén mutatkozó különbözô nehézségeket az Érzelemszabályozási Nehézség Kérdôív (Difficulties in Emotion Regulation Scale; DERS; Gratz és Roemer, 2004) rövidített változatával (Brief version of the Difficul- 
ties in Emotion Regulation Scale; DERS-16; Bjureberg és mtsai, 2016) mértük fel. A DERS-16 az eredeti, 36 tételes kérdôív (DERS) hat faktora közül ötöt ôrzött meg: az Érzelmi tudatosság hiánya faktor (mennyire figyel valaki az érzelmi jelzéseire) ugyanis a rövid változatban nem jelenik meg. A DERS-16-ot az alábbi skálák építik fel: (1) az Érzelmi reakciók elfogadhatatlansága faktor azt a folyamatot ragadja meg, amikor a személy negatív érzelmeire további negatív érzelmekkel reagál; a (2) Nehézségek a célirányos viselkedés fenntartásában faktor a negatív érzelmek nyomán megjelenô koncentrációs nehézségeket jelzi; az (3) Impulzuskontroll nehézségek faktor a negatív emóciókra adott viselkedésszabályozási problémákat méri fel; az (4) Érzelemszabályozó stratégiákhoz való csökkent hozzáférés faktor a negatív érzelmek megjelenéséhez kapcsolódó azon hiedelmet írja le, mely szerint az ilyen állapot elhúzódó lesz. Végül az (5) Érzelmi tisztaság hiánya faktor azt összegzi, hogy valaki milyen mértékben képes azonosítani az éppen általa átélt érzelmet. A tételekre 1-tôl (szinte soha [az esetek 0-10\%-ában]) 5-ig (szinte mindig [az esetek 91-100\%-ában]) tartó skálán lehet válaszolni. A kérdôív összpontszáma általában mutatja meg az érzelemreguláció terén mutatkozó problémákat, míg az egyes skálák összesített pontszáma az adott érzelemszabályozó alapstratégia múködési nehézségét jelzi. A teljes DERS-16 reliabilitása kiváló (Cronbach- $\alpha=0,92$ ), konstruktruktumvaliditása pedig az eredeti változattal (DERS) megegyezô volt (Bjureberg és mtsai, 2016). Saját vizsgálatunkban a kérdôív szintén kiváló megbízhatóságot mutatott (Cronbach- $\alpha=0,92)$. A DERS magyar változatát Kökönyei és munkatársai készítették el (Kökönyei, Urbán, Reinhardt, Józan és Demetrovics, 2014).

\section{Önkritikus Rumináció Kérdôiv}

Az énre irányuló perszeveratív kritikus gondolkodási stílust a tíztételes Önkritikus Rumináció Kérdôívvel (Self-Critical Rumination Scale; SCRS; Smart, Peters és Baer, 2016) mértük fel. A tételeket négyfokú skálán ( 1 = egyáltalán nem és 4 = nagyon között) értékeli a kitöltô. Maximum 40 pont szerezhetô az egyfaktoros kérdôíven, amely kiváló reliabilitást mutatott annak bevezetô tanulmányában (Cronbach- $\alpha=0,92$; Smart és mtsai, 2016). Ezt saját vizsgálatunk is megerôsítette (Cronbach- $\alpha=0,91$ ). A kifejezettebb önkritikus rumináció negatívabb önértékeléssel, magasabb depresszió-, szorongás- és distresszpontszámokkal, valamint magasabb szégyenérzettel társult (Smart és mtsai, 2016). A magyar változatot Kökönyei Gyöngyi és munkacsoportja készítette, a kérdôív magyar adaptációja folyamatban van.

\section{Tapasztalati Elkerülés Kérdő̀v}

A Tapasztalati Elkerülés Kérdőív (Avoidance and Fusion Questionnaire for Youth, AFQ-Y8; Greco, Lambert és Baer, 2008) a kognitív rugalmasság/rugalmatlanság nyolctételes, egyfaktoros mérôeszköze: a tapasztalatok (pl. emlékek, gondolatok, érzelmek) elkerülésének tendenciáit azonosítja. Az elkerülés amiatt történik, mert a személy úgy véli, hogy kognitív folyamatai összezavarják, megzavarják múködési folyamatait. Tételeit ötfokozatú skálán ítéli meg magára vonatkozóan a kitöltô 0-tól (egyáltalán nem igaz) 4-ig (nagyon igaz). Az összpontszám így 0-tól (magas pszichés rugalmasság) 32-ig (magas pszichológiai rugalmatlanság) változhat. A magasabb pontszám viselkedéses prob- 
lémákkal, valamint mentális és szomatikus betegségtünetekkel asszociálódik (Greco és mtsai, 2008). A kognitív inflexibilitás mellett Renshaw (2017) vizsgálata szerint a kérdôív - 15 pont felett - klinikai szintú internalizáló tünetképzést is jelez. A mérôeszköz reliabilitása kiváló (Cronbach- $\alpha=0,83$; Greco és mtsai, 2008). Magyar változata is megfelelố belsố megbízhatósággal (Cronbach- $\alpha=0,74)$ jellemezhetô (Szemenyei és mtsai, 2020). Ugyanezt erôsítette meg jelen kutatás is (Cronbach- $\alpha=0,70)$.

\section{Eljárás}

Keresztmetszeti kérdôíves kutatásunkat 2019 februárja és 2020 januárja között folytattuk le 14 középiskolában (gimnáziumokban és szakgimnáziumokban), 9., 10., 11. és 12. évfolyamos tanulók körében. Összesen 5 fôvárosi és 9 vidéki középiskola vett részt a felmérésben hozzáférhetôségi mintavétellel. Az intézményvezetôk írásos engedélyét követốen a középiskolákban képzett vizsgálatvezetôk ismertették a kamaszokkal a vizsgálat célját egy osztályfőnöki óra elején. A fiatalok egy-egy tájékoztató és beleegyezô nyilatkozatot vittek haza saját maguk és szüleik részére. A vizsgálatban azok a 14 éven felüli fiatalok vehettek részt, akik és akiknek a szülője ahhoz írásos beleegyezését adta. A kérdôívcsomag kitöltése a beleegyezô nyilatkozatok beérkezését követôen egy osztályfőnöki óra keretében zajlott - az iskolák informatikai felszereltségétôl függóen - vagy online formában egy számítógépteremben $(\mathrm{N}=524 ; 51,6 \%)$, vagy nyomtatott formában a tanulók osztálytermében $(\mathrm{N}=491 ; 48,4 \%)$. A kétféle kitöltési forma gyakoriságában nemi különbség nem mutatkozott $\left(\chi^{2}[1]=2,51 ; p=0,113 ; \varphi=0,05\right)$. Ugyanakkor az életkor $[\mathrm{t}(1007)=3,47 ; \mathrm{p}<0,001 ; \mathrm{d}=1,26)$ és a lakóhely típusa szerint szignifikáns különbség körvonalazódott a két kitöltési mód között. Az online formában kitöltést végzốk átlagéletkora 16,66 év volt ( $\mathrm{SD}=1,49)$, míg az osztálytermi kitöltésben részt vevôk átlagosan 16,97 évesen $(\mathrm{SD}=1,31)$ végezték a kitöltést. A Budapesten éloók közül szignifikánsan több diák töltötte ki online a kérdőívet (83,4\%-uk), mint a vidéki városok tanulói (34,9\%-uk), a községben élôk körében e tekintetben nem volt különbség $\left[\chi^{2}(2)=153,03 ; \mathrm{p}<0,0001 ; \varphi=0,40\right]$.

A kitöltést a vizsgálatvezetôk felügyelték, annak során az iskola személyzete nem volt jelen. A vizsgálatban való részvételért jutalom nem járt. A vizsgálatot követôen minden tanuló kapott egy brosúrát, amelyben pszichológiai segítségnyújtás konkrét elérhetôségei szerepeltek. Továbbá a vizsgálatvezetôk az adatfelvételt követôen az iskolában maradtak, hogy igény szerint a kamaszok felvetôdô kérdéseit megválaszolhassák.

\section{Statisztikai elemzés}

A minta leíró jellemzôinek megadása mellett (gyakoriság, átlag, szórás) a kutatásban validált kérdốiv (ISAS-HU) két nagyobb egységének mintánkra vonatkozó eredményeit szintén gyakorisági adatokkal és átlagértékekkel mutatjuk be. A demográfiai adatokat és az ISAS-HU leíró statisztikai adatait független mintás t-próbával és $\chi^{2}$-négyzet próbával hasonlítottuk össze a lányok és a fiúk mintájában. Az összefüggések erôsségét független mintás t-próba esetén Cohen-d (Cohen, 1992), $\chi^{2}$-négyzet próbánál pedig $\varphi$ 
hatásméret-mutatóval teszteltük. A kérdôívek belsô konzisztenciáját a Cronbach-alfa mutatóval adtuk meg.

Az ISAS-HU kérdôív adaptációjának fontos lépéseként elvégeztük a mérôeszköz II. részének megerôsítő faktorelemzését (Confirmatory Factor Analysis, CFA és Exploratory Structural Equation Modeling, ESEM-elemzések segítségével). CFA esetében a kereszttöltéseket 0-ban rögzítjük, az ESEM-elemzés esetében azonban azokat 0-hoz közelítve specifikáljuk, ezzel a CFA-val azonosított faktorok közötti esetleges magas korreláció csökkenhet, a faktorszerkezetrôl ezzel komplexebb, reálisabb kép jelenik meg. Az ESEM-elemzést azok a korábbi eredmények is indokolták, melyek rámutattak, hogy az ISAS II. felének bizonyos tételei (pl. az Önmagáról való gondoskodás) mindkét (intra- és interperszonális) faktorra erôsebben töltôdnek (Klonsky és Glenn, 2009). Becslési eljárásként a WLSMV (súlyozott legkisebb négyzetes becslési eljárás, Weighted Least Squares Mean and Variance adjusted; Finney és DiStefano, 2006) módszert alkalmaztuk. Ez a becslési eljárás a tételekre adott válaszokat - a faktorok indikátorait - ordinális változóként kezeli, ami megfelelố azokban az esetekben, ahol plafon- vagy padlóhatás várható a válaszok eloszlásában. A tesztelt modellek illeszkedését CFI- (öszszehasonlító illeszkedési mutató, Comparative Fit Index), TLI (Tucker-Lewis illeszkedési mutató) és RMSEA- (a megközelítés hibáját a modell komplexitását figyelembe vevô módon méró index, Root Mean Square Error of Approximation) mutatókkal ellenôriztük. A CFI- és a TLI-mutatók esetében a 0,95 vagy az afölötti értékeket, az RMSEA-mutatónál pedig a 0,05 vagy az annál kisebb értéket tekintettük megfelelônek. Elsôként egy egyfaktoros, majd a Klonsky és Glenn (2009) által leírt kétfaktoros megoldásokat teszteltük CFA-val, végül a kétfaktoros szerkezetet ESEM-elemzéssel. Az ISAS-HU II. felének nemi invariancia tesztelését a faktortöltésekben a lányok és a fiúk között mutatkozó nagy eltérések miatt nem tudtuk elvégezni.

A kérdőív-validáció keretében az ISAS-HU skála második felének konvergens validitását Pearson-féle korrelációs elemzéssel, Bonferroni-korrekcióval kiegészítve teszteltük. A kipróbáló és a repetitív önsértô csoportokat a különbözô mentális egészségmutatók mentén független mintás t-próbával vetettük össze, minden esetben a hatásméretet (Cohen-d) is meghatároztuk. Az aktuálisan önsértôk, a korábban önsértôk és a sohasem önsértook összehasonlítása a felmért változók mentén pedig egy szempontos varianciaanalízissel (ANOVA) történt. A csoportok páronkénti összehasonlítására Tukey-féle utóelemzést alkalmaztunk. A hatásméretet f-fel (Cohen, 1988) becsültük.

Elemzéseinkhez az SPSS 26.0 és az Mplus 8.0 (Muthén és Muthén, 1998-2017) statisztikai programcsomagokat alkalmaztuk.

A szignifikanciaszintet általánosságban 95\%-os megbízhatósági szinten határoztuk meg, korrelációs elemzések esetében pedig Bonferroni-korrekció alapján.

\section{Etikai vonatkozások}

A kutatás megkezdéséhez és lefolytatásához szükséges etikai engedélyt az Eötvös Loránd Tudományegyetem Pedagógiai és Pszichológiai Kar Kutatásetikai Bizottsága adta ki 2018 decemberében. Továbbá a vizsgálatvezetôk a kutatást a Helsinki Nyilatko- 
zat (WHO, 2001) etikai alapelveivel összhangban folytatták le. A tesztcsomagot csak azok a kamaszok tölthették ki, akik és akiknek az egyik szülője - a vizsgálat céljáról és körülményeirôl való írásos tájékoztatást követôen - írásos beleegyezésüket adták a részvételhez. A kérdőívek kitöltésénél személyes beazonosításra alkalmas adatot nem gyújtöttünk. A vizsgálatban való részvétel önkéntes volt.

\section{EREDMÉNYEK}

\section{Az önsértô viselkedés leíró jellemzői a mintában}

A vizsgált serdülők 58,8\%-a $(\mathrm{N}=597)$ sohasem végzett önsértést, míg 41,2\%-uk $(\mathrm{N}=418)$ beszámolt arról, hogy már önsértett legalább egyszer valamilyen módon (a lányok 44\%-a [N = 295], míg a fiúk 35,7\%-a [N = 122]). Az életükben legalább egyszer önsértést végzốk közül 77\% ( $\mathrm{N}=322$, a teljes minta 31,7\%-a) az elmúlt hónapban követett el valamilyen önsértést. Az önsértô státuszban - kis hatásméret mellett - nemi különbséget mutattunk ki $\left[\chi^{2}(2)=10,220 ; p=0,006 ; \varphi=0,100\right]$. A lányok nagyobb arányban folytatnak aktuálisan valamilyen önsértô viselkedést. Ezzel összhangban a fiúk közül többen, mint a lányok sohasem végeztek önsértést életük folyamán. A nôi nem közel másfélszeresére emeli az esélyét az önsértés élettartam-prevalenciájának $(\mathrm{OR}=1,42[1,08-1,85], p=0,011)$.

Az aktuálisan önsértôk többsége $(88,5 \%, \mathrm{~N}=284)$ az elmúlt hónapban 1-5 nap között végzett önsértést, 3,7\%-uk ( $\mathrm{N}=12)$ 6-10 nap közötti gyakorisággal, 2,2\%-uk ( $\mathrm{N}=7)$ 11-15 nap között, míg 5,6\%-uk $(\mathrm{N}=18)$ több mint a hónap felében jelezte önsértô cselekedet elôfordulását. Az önsértés súlyosságának egyik fontos mutatója a többféle önsértési mód alkalmazása (versatility; Gratz, Dixon-Gordon, Chapman és Tull, 2015). Mintánkban a jelenleg (az elmúlt egy hónapban) önsértók egyötöde $(21,7 \% ; \mathrm{N}=70)$ egyféle önsértést használ, a többség azonban többféle módot (78,3\%; $\mathrm{N}=252)$. E tekintetben nemi különbség nem mutatkozott.

Az önsértés leggyakoribb módjai az önütés (54,8\%; $\mathrm{N}=176)$ és a sebgyógyulás megakadályozása $(53,9 \% ; \mathrm{N}=173)$. Gyakori még a harapás $(41,7 \% ; \mathrm{N}=134)$, a vágás $(41,4 \% ; \mathrm{N}=133)$, a testfelület megcsípése $(38,6 \% ; \mathrm{N}=124)$ és megkarmolása $(38,3 \%$; $\mathrm{N}=123)$. A legritkább önsértési mód a mintánkban a veszélyes anyag lenyelése $(7,5 \%$; $\mathrm{N}=24)$ volt. A lányok körében a bőr megvágása, az abba való belevésés és annak erôs megkarmolása szignifikánsan gyakoribb, mint a fiúknál, míg az önütés a fiúknál fordul elô nagyobb arányban. A részletes eredményeket az 1. táblázat tartalmazza.

Az életük folyamán önsértésrôl beszámoló fiatalok $(\mathrm{N}=418)$ átlagosan 12 éves korukban ( $\left.a_{\text {kor }}=11,97 ; \mathrm{SD}=3,55\right)$ végeztek először önsértést. Az önsértés kipróbálása, illetve indulása a 12 és 15 éves kor közötti idôszakban volt a legjellemzôbb a mintánkban. A valaha vagy aktuálisan önsértók kétharmada $(68,7 \% ; \mathrm{N}=287)$ A valaha vagy aktuálisan önsértốk kétharmada $(68,7 \%$; N=287) ún. repetitív önsértố (recurrent NSSI; Gratz és mtsai., 2015), akik 10 vagy annál több önsértési epizód elôfordulásáról számoltak be életük során. Az önsértô serdülôkk közel egyharmada (31,3\%; N=131) pedig ún. kipróbáló önsértô (occasional self-harmers; Gratz és mtsai., 2015): ók életük folyamán kevesebb mint 10 önsértési epizódban vettek részt. Nemi különbséget az önsér- 
1. táblázat. A mintára jellemzó önsértési adatok

\begin{tabular}{|c|c|c|c|c|}
\hline Változó & $\begin{array}{l}\text { Teljes mint } a \\
\mathrm{~N}=1015 \\
\%(\mathrm{~N})\end{array}$ & $\begin{array}{c}\text { Lány } \\
\mathrm{N}=671^{*} \\
\%(\mathrm{~N})\end{array}$ & $\begin{array}{c}\text { Fiú } \\
\mathrm{N}=342^{*} \\
\%(\mathrm{~N})\end{array}$ & $\begin{array}{l}\text { A csoportok közöt- } \\
\text { ti különbséget jelzô } \\
\text { próbastatisztika }\end{array}$ \\
\hline \multicolumn{5}{|l|}{ Önsértő-e } \\
\hline sohasem & $58,8(597)$ & $56,0(376)$ & $64,3(220)$ & \multirow{3}{*}{$\begin{array}{l}\chi^{2}(2)=10,220 \\
p=0,006 \\
\varphi=0,100\end{array}$} \\
\hline korábban & $9,5(96)$ & $9,0(60)$ & $10,6(36)$ & \\
\hline jelenleg & $31,7(322)$ & $35,0(235)$ & $25,1(86)$ & \\
\hline \multicolumn{5}{|l|}{$\begin{array}{l}\text { Jelenleg önsértô } \\
\text { hány önsértési } \\
\text { módot használ }\end{array}$} \\
\hline egyféle & $21,7(70)$ & $20,8(49)$ & $24,5,(21)$ & \multirow{2}{*}{$\begin{array}{l}\chi^{2}(11)=10,224 \\
p=0,510 \\
\varphi=0,178\end{array}$} \\
\hline többféle & $78,3(252)$ & $79,2(186)$ & $75,5(65)$ & \\
\hline \multicolumn{5}{|l|}{$\begin{array}{l}\text { Önsértés havi } \\
\text { gyakorisága az } \\
\text { elmúlt hónapban }\end{array}$} \\
\hline 1-5 nap között & $88,5(285)$ & $88,1(207)$ & $89,6(77)$ & \multirow{4}{*}{$\begin{array}{l}\chi^{2}(3)=0,662 \\
p=0,882 \\
\varphi=0,045\end{array}$} \\
\hline 6-10 nap között & $3,7(12)$ & $4,3(10)$ & $2,3(2)$ & \\
\hline $\begin{array}{l}\text { 11-15 nap kö- } \\
\text { zött }\end{array}$ & $2,2(7)$ & $2,1(5)$ & $2,3(2)$ & \\
\hline $\begin{array}{l}\text { több mint } \\
15 \text { napon }\end{array}$ & $5,6(18)$ & $5,5(13)$ & $5,8(5)$ & \\
\hline \multicolumn{5}{|l|}{$\begin{array}{l}\text { Önsértési módok } \\
\text { gyakorisága a } \\
\text { jelenleg önsértôk } \\
\text { körében }\end{array}$} \\
\hline vágás & $41,4(133)$ & $47,2(111)$ & $25,6(22)$ & $\begin{array}{l}\chi^{2}(1)=12,164 \\
p<0,0001 \\
\varphi=0,195\end{array}$ \\
\hline harapás & $41,7(134)$ & $41,7(98)$ & $41,9(36)$ & $\begin{array}{l}\chi^{2}(1)=0,001 \\
p=0,980 \\
\varphi=0,001\end{array}$ \\
\hline égetés & $20,9(67)$ & $19,1(45)$ & $25,6(22)$ & $\begin{array}{l}\chi^{2}(1)=1,577 \\
p=0,209 \\
\varphi=0,070\end{array}$ \\
\hline bőrbe vésés & $31,5(101)$ & $34,5(81)$ & $23,3(20)$ & $\begin{array}{l}\chi^{2}(1)=3,670 \\
p=0,055 \\
\varphi=0,107\end{array}$ \\
\hline erôs csípés & $38,6(124)$ & $40,9(96)$ & $32,6(28)$ & $\begin{array}{l}\chi^{2}(1)=1,826 \\
p=0,177 \\
\varphi=0,075\end{array}$ \\
\hline hajkitépés & $18,4(59)$ & $19,6(46)$ & $15,1(13)$ & $\begin{array}{l}\chi^{2}(1)=0,834 \\
p=0,361 \\
\varphi=0,051\end{array}$ \\
\hline erôs karmolás & $38,3(123)$ & $43,0(101)$ & 25,6 22) & $\begin{array}{l}\chi^{2}(1)=8,062 \\
p=0,005 \\
\varphi=0,158\end{array}$ \\
\hline
\end{tabular}




\begin{tabular}{l|c|c|c|l}
\hline Változó & $\begin{array}{c}\text { Teljes minta } \\
\mathrm{N}=1015 \\
\%(\mathrm{~N})\end{array}$ & $\begin{array}{c}\text { Lány } \\
\mathrm{N}=671^{*} \\
\%(\mathrm{~N})\end{array}$ & $\begin{array}{c}\text { Fiú } \\
\mathrm{N}=342^{*} \\
\%(\mathrm{~N})\end{array}$ & $\begin{array}{l}\text { A csoportok közöt- } \\
\text { ti különbséget jelzó } \\
\text { próbastatisztika }\end{array}$ \\
\hline önütés & $54,8(176)$ & $50,6(119)$ & $66,3(57)$ & $\begin{array}{l}\chi^{2}(1)=6,219 ; \\
p=0,013 ; \\
\varphi=0,139\end{array}$ \\
\hline $\begin{array}{l}\text { sebgyógyulás } \\
\text { megakadályozása }\end{array}$ & $53,9(173)$ & $56,2(132)$ & $47,7(41)$ & $\begin{array}{l}\chi^{2}(1)=1,829 ; \\
\mathrm{p}=0,176 ; \\
\varphi=0,075\end{array}$ \\
\hline $\begin{array}{l}\text { bốr falnak dör- } \\
\text { zsölése }\end{array}$ & $19,3(62)$ & $18,7(44)$ & $20,9(18)$ & $\begin{array}{l}\chi^{2}(1)=0,197 ; \\
\mathrm{p}=0,657 ; \\
\varphi=0,025\end{array}$ \\
\hline $\begin{array}{l}\text { bốr megszúrása } \\
\text { túvel }\end{array}$ & $27,1(87)$ & $27,7(65)$ & $25,6(22)$ & $\begin{array}{l}\chi^{2}(1)=0,138 ; \\
\mathrm{p}=0,711 ; \\
\varphi=0,021\end{array}$ \\
\hline $\begin{array}{l}\text { veszélyes anyag } \\
\text { lenyelése }\end{array}$ & $7,5(24)$ & $6,8(16)$ & $9,3(8)$ & $\begin{array}{l}\chi^{2}(1)=0,566 ; \\
\mathrm{p}=0,452 ; \\
\varphi=0,042\end{array}$ \\
\hline
\end{tabular}

Megjegyzés: *Két fô nem adta meg a nemét.

tés gyakoriságában (kipróbáló vagy ismétlôdô önsértés) nem igazoltunk $\left[\chi^{2}(1)=2,15\right.$; $\mathrm{p}=0,14 ; \varphi=0,07]$.

A teljes (korábban és jelenleg) önsértó minta 33,8\%-a ( $\mathrm{N}=129)$ fájdalmasként élte meg az önsértố epizódokat, 44,1\%-uk $(\mathrm{N}=157)$ csak ritkán tapasztalt fájdalmat, míg 25,1\%-uk ( $\mathrm{N}=96)$ egyáltalán nem számolt be az önsértéshez kapcsolódó fájdalomélményrôl. A legtöbb önsértô (62,2\%; $\mathrm{N}=237)$ egyedül végezte az önsértést, 22,8\%-uk $(\mathrm{N}=87)$ olykor egyedül, máskor másokkal együtt önsértett, $15 \%(\mathrm{~N}=57)$ mindig mások társaságában volt az önsértés során. Az önsértésre való késztetettség kapcsán két szélsôség jellemezte mintánkat: 42,2\% (N = 154) az önsértésre irányuló késztetés megjelenését követô egy órában végre is hajtotta tettét, míg körülbelül ugyanennyien $(44,4 \% ; \mathrm{N}=162)$ több mint egy napot is képesek várni a megjelenô motiváció és a végrehajtás között. A legtöbb önsértő (82,3\%; $\mathrm{N}=302)$ szerette volna vagy szeretné, ha abba tudná hagyni az önsértést, a többiek $(17,7 \%, \mathrm{~N}=65)$ azonban ragaszkodnak az önsértô viselkedéshez.

\section{Az önsértés hátterében álló okok dimenziói - Az ISAS-HU megerôsitő faktorelemzésének} eredményei

Az ISAS-HU II. részének megerôsítô faktorelemzése során a legjobban illeszkedô faktorszerkezet kiválasztása érdekében három modellt vizsgáltunk: (1) egy CFA-n alapuló egyfaktoros modellt; (2) egy CFA-val tesztelt kétfaktoros modellt és (3) egy ESEM-elemzésen alapuló kétfaktoros modellt. A kétfaktoros modellek megegyeztek az eredeti Klonsky és Glenn (2009) féle faktorszerkezettel. Az eredmények szerint a tételek kereszttöltéseit is megengedô kétfaktoros ESEM-megoldás megfelelô illeszkedést mutatott. A modifikációs indexek vizsgálatát követốn a Szívósság kifejezése és a 
Szenzoros élménykeresés alskálák között megengedett hibakorreláció tovább növelte a modell illeszkedését (4. modell). A 4. modell illeszkedését a fiúk és a lányok almintáiban külön-külön is teszteltük. Az egyes modellek illeszkedési mutatóit a 2. táblázatban foglaltuk össze.

2. táblázat. Illeszkedési mutatók az Állítások az Önsértés Kapcsán Kérdôív II. részének (funkciók) versengó modelljei között

\begin{tabular}{|c|c|c|c|c|c|}
\hline & $\chi^{2}$ & $\mathrm{df}$ & CFI & TLI & RMSEA [90\% CI] \\
\hline Modell 1: Egyfaktoros CFA & 621,5 & 65 & 0,689 & 0,627 & $\begin{array}{c}0,157 \\
{[0,146-0,168]}\end{array}$ \\
\hline $\begin{array}{l}\text { Modell 2: Kétfaktoros CFA } \\
\text { (Klonsky és Glenn, 2009) }\end{array}$ & 489,9 & 64 & 0,762 & 0,710 & $\begin{array}{c}0,138 \\
{[0,127-0,150]}\end{array}$ \\
\hline $\begin{array}{l}\text { Modell 3: Kétfaktoros ESEM-modell } \\
\text { (Klonsky és Glenn, 2009) }\end{array}$ & 175,2 & 53 & 0,932 & 0,900 & $\begin{array}{c}0,081 \\
{[0,068-0,095]}\end{array}$ \\
\hline $\begin{array}{l}\text { Modell 4: Kétfaktoros ESEM-modell } \\
\text { (Klonsky és Glenn, 2009) } \\
\text { módosítással* }\end{array}$ & 134,3 & 52 & 0,954 & 0,931 & $\begin{array}{c}0,067 \\
{[0,053-0,081]}\end{array}$ \\
\hline \multicolumn{6}{|l|}{$\begin{array}{l}\text { Illeszkedési mutatók a két nem eseté- } \\
\text { ben (Modell } 4 \text { alapján) }\end{array}$} \\
\hline 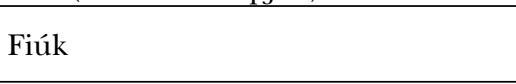 & 89,1 & 52 & 0,960 & 0,940 & $\begin{array}{c}0,086 \\
{[0,054-0,116]}\end{array}$ \\
\hline Lányok & 102,2 & 52 & 0,954 & 0,931 & $\begin{array}{c}0,062 \\
{[0,044-0,080]}\end{array}$ \\
\hline
\end{tabular}

Megjegyzés: * = Megengedett hibatagok közötti korreláció a Szívósság kifejezése és a Szenzoros élménykeresés alskálák között. $\chi^{2}$ = Khí-négyzet teszt; CFI = Comparative Fit Index; TLI = Tucker-Lewis Index; RMSEA $=$ Root Mean Squared Error of Approximation. A Khí-négyzet teszt minimum $\mathrm{p}<0,05$ szinten szignifikáns. $\mathrm{N}=349$.

Eredményeink két faktor - egy intra- és egy interperszonális funkciókör - markáns jelenlétét jelzik a teljes önsértô mintában, és a két nem esetében külön-külön is. A Személyközi határok szabályozása, a Szívósság kifejezése, a Distressz jelzése és az Autonómia kifejezése alskálák között erôs kereszttöltés figyelhetô meg a teljes mintában és a lányok csoportjában. Ezek az alskálák mind az intra-, mind az interperszonális faktorra súlyozódnak. A fiúknál az alskálák között több esetben figyelhetố meg kereszttöltés, valamint kiemelendő, hogy minden alskála erôs súlyozódást mutat az interperszonális faktorra. A faktortöltés mintázat különbözősége felveti, hogy a két nem esetében eltérô lehet a faktorstruktúra. Ugyanakkor az önsértô fiúk alacsony száma $(\mathrm{N}<100)$ miatt a nemi invariancia tesztelésétôl elemzéseinkben el kellett tekintenünk. A faktortöltéseket a 3. táblázatban szerepeltetjük.

A teljes mintában a két faktor jó megbízhatósági értékekkel írható le (Cronbach- $\alpha_{\text {intraperszonális }}=0,84$ és Cronbach- $\alpha_{\text {interperszonális }}=0,82$ ). Hasonlóképpen a lányok mintájában is megfelelőek a reliabilitás adatai (Cronbach- $\alpha_{\text {intraperszonális }}=0,84$ és Cronbach- $\left.\alpha_{\text {interperszonális }}=0,79\right)$ (4. táblázat). 
3. táblázat. Standardizált faktortöltések a kétfaktoros ESEM-megoldás (Modell 4) esetén

\begin{tabular}{l|c|c|c|c|c|c}
\hline & \multicolumn{2}{|c|}{ Teljes minta } & \multicolumn{2}{c|}{ Fiúk } & \multicolumn{2}{c}{ Lányok } \\
\hline Funkciók & $\begin{array}{c}\text { Intra- } \\
\text { perszo- } \\
\text { nális } \\
\text { faktor }\end{array}$ & $\begin{array}{c}\text { Interper- } \\
\text { szonális } \\
\text { faktor }\end{array}$ & $\begin{array}{c}\text { Intra- } \\
\text { perszo- } \\
\text { nális } \\
\text { faktor }\end{array}$ & $\begin{array}{c}\text { Interper- } \\
\text { szonális } \\
\text { faktor }\end{array}$ & $\begin{array}{c}\text { Intra- } \\
\text { perszo- } \\
\text { nális } \\
\text { faktor }\end{array}$ & $\begin{array}{c}\text { Interper- } \\
\text { szonális } \\
\text { faktor }\end{array}$ \\
\hline Érzelemszabályozás & 0,781 & 0,134 & $-0,096$ & 0,566 & 0,810 & 0,158 \\
\hline Önbüntetés & 0,753 & 0,157 & 0,021 & 0,611 & 0,770 & 0,155 \\
\hline $\begin{array}{l}\text { Disszociáció megszün- } \\
\text { tetése }\end{array}$ & 0,806 & 0,247 & $-0,065$ & 0,739 & 0,833 & 0,244 \\
\hline $\begin{array}{l}\text { Öngyilkossági gondola- } \\
\text { tok megelózése }\end{array}$ & 0,029 & 0,540 & 0,584 & 0,504 & $-0,001$ & 0,528 \\
\hline Distressz jelzése & 0,686 & 0,517 & 0,161 & 0,904 & 0,692 & 0,494 \\
\hline $\begin{array}{l}\text { Személyközi határok } \\
\text { szabályozása }\end{array}$ & 0,524 & 0,525 & 0,335 & 0,699 & 0,582 & 0,529 \\
\hline Gondoskodás önmagáról & 0,127 & 0,732 & 0,670 & 0,720 & 0,128 & 0,694 \\
\hline Szenzoros élménykeresés & 0,272 & 0,484 & 0,371 & 0,697 & 0,325 & 0,380 \\
\hline Kötódés a kortársakhoz & $-0,178$ & 0,772 & 0,998 & 0,570 & $-0,195$ & 0,707 \\
\hline $\begin{array}{l}\text { Interperszonális figyelem } \\
\text { kiváltása }\end{array}$ & 0,153 & 0,700 & 0,518 & 0,740 & 0,109 & 0,705 \\
\hline Szívósság kifejezése & 0,406 & 0,452 & $-0,116$ & 0,532 & 0,441 & 0,545 \\
\hline Autonómia kifejezése & 0,300 & 0,784 & 0,492 & 0,743 & 0,333 & 0,821 \\
\hline Bosszú kifejezése & 0,242 & 0,704 & 0,665 & 0,787 & 0,295 & 0,613 \\
\hline $\begin{array}{l}\text { Faktorok közötti } \\
\text { korreláció }\end{array}$ & $-0,25$ & $-0,34$ & & $-0,33$ \\
\hline
\end{tabular}

Megjegyzés: Target rotáció került alkalmazásra, mely megengedi, hogy közvetlenül vizsgáljuk az elforgatott faktor töltésmátrixa és az elvárt faktortöltés mintázata közötti egyezést. A jelentôs (0,30 feletti) faktortöltések dôlttel szedve. $\mathrm{N}=348 . \mathrm{N}_{\text {fiúk }}=96 . \mathrm{N}_{\text {lányok }}=252$.

\section{A vizsgált változók kapcsolata - Az ISAS-HU konvergens validitása a lányok mintájában}

Mivel a faktorszerkezet tesztelésekor felvetôdött annak különbözósége a lányok és a fiúk között, ezért további elemzéseinket csak az önsértô lányok körében végeztük el. Ennek szükségességét erôsítette az önsértô fiúk alacsony mintaelemszáma is. A lányok körében elsôként feltártuk az önsértés funkcióinak (intra- és interperszonális funkciókör) a vizsgált mentális egészségváltozókkal való kapcsolatát (4. táblázat). Az elvártak szerint az önsértés intraperszonális háttere közepes mértékben, pozitív irányban jár együtt a fokozott magányossággal, a mentálisbetegség-tünetek mutatóival, így az internalizáló pszichés problémákkal, valamint az érzelemszabályozás nehézségeivel, az önkritikus rágódással és a kognitív inflexibilitással. Továbbá szintén egyenes irányban, de gyenge mértékben kapcsolódik az externalizáló pszichés tünetekkel. Az önsértés inter- 
4. táblázat. Az önsértés intra- és interperszonális okainak összefüggései a vizsgált változókkal a lányok mintájában

\begin{tabular}{l|c|c}
\hline \multirow{2}{*}{} & \multicolumn{2}{|c}{ ISAS-HU funkciók } \\
\cline { 2 - 3 } & $\begin{array}{c}\text { Intraperszonális } \\
\text { faktor }\end{array}$ & $\begin{array}{c}\text { Interperszonális } \\
\text { faktor }\end{array}$ \\
\hline kor & 0,06 & $-0,10$ \\
\hline magányosság & $-0,38^{* * *}$ & 0,07 \\
\hline SDQ összprobléma & $0,37 * * *$ & 0,09 \\
\hline SDQ internalizáló tünetek & $0,35 * * *$ & $-0,01$ \\
\hline SDQ externalizáló tünetek & $0,23^{* * *}$ & $0,17 * *$ \\
\hline SDQ proszocialitás & $-0,02$ & 0,04 \\
\hline DERS-16 össz & $0,42^{* * *}$ & 0,06 \\
\hline SCRS össz & $0,44^{* * *}$ & $-0,03$ \\
\hline AFQ-Y8 össz & $0,44^{* * *}$ & 0,06 \\
\hline
\end{tabular}

Megjegyzés: $\mathrm{N}=253$. ISAS-HU = Állítások az Önsértés Kapcsán Kérdőív. SDQ = Képességek és Nehézségek Kérdőív. DERS-16 = Érzelemszabályozási Nehézség Kérdőív rövid változat. SCRS = Önkritikus Rumináció Kérdőív. AFQ-Y8 = Tapasztalati Elkerülés Kérdőív. $* p<0,05 ; * * p<0,01 ; * * * p<0,0001$. Vastaggal szedve a Bonferronikorrekciót $(\mathrm{p}<0,0028)$ követően is szignifikáns értékek. ${ }^{+}=$fordított skála.

perszonális motivációi ugyanakkor nem mutattak kapcsolatot ezekkel a változókkal. Az életkor és a proszociális magatartás egyik önsértő funkciókörrel sincs kapcsolatban.

Az önsértést valaha vagy aktuálisan folytató lányok között felmértük továbbá az ún. kipróbálók (kevesebb mint 10 önsértési epizód az elôzményben; Gratz és munkatársai, 2015) és a repetitív önsértôk (10 vagy annál több önsértési epizód az élet folyamán; Gratz és munkatársai, 2015) pszichés státuszának különbségeit. Eredményeink egyértelmúen rámutattak, hogy a repetitív önsértô kamaszlányok önsértésének hátterében erôteljesebben húzódnak meg az intraperszonális motívumok, mint a kipróbálók motivációjában. Az önsértés interperszonális motivációjában azonban nem mutatkozott eltérés a két súlyosságú csoport között. A repetitív önsértôkk szignifikánsan több pszichés tünettel és érzelemszabályozási nehézséggel küzdenek, és magányosabbnak érzik magukat, mint a kipróbálók. Továbbá a repetitív önsértôk a mentális betegségek kialakulásában transzdiagnosztikus rizikófaktorként értékelhetó önkritikus rumináció és kognitív rugalmatlanság (Im és Kahler, 2020) tekintetében is magasabb pontszámot értek el, mint a kipróbálók. Érdemes kiemelni, hogy az önsértést csupán kipróbáló lányok a kognitív inflexibilitást (tapasztalati elkerülést) felmérô kérdőíven a Renshaw (2017) által megállapított, klinikai szintú neurotikus tünetképzést jelzô 15 pontos vágóérték alatti átlagpontszámot (á $=13,19 ; \mathrm{SD}=5,20)$ értek el. Ellenben a repetitív önsértô lányok e tekintetben átlagosan már a veszélyzónába (á = 16,44; SD = 5,69) kerültek.

\section{Önsértố csoportok összehasonlítása a mentális egészség mutatói alapján a teljes mintában}

Végül a teljes mintára összpontosítva összehasonlítottuk a sohasem, a korábban (több mint egy hónapja) és az aktuálisan (egy hónapon belül) önsértô kamaszokat a mentális egészség fentebb bemutatott markerei (magányosság érzése, internalizáló és ex- 
5. táblázat. A kipróbáló és a repetitív önsértố lányok összehasonlítása a mentális egészség és az érzelemszabályozás mutatói mentén

\begin{tabular}{|c|c|c|c|c|}
\hline Változó & $\begin{array}{c}\text { Kipróbáló } \\
\text { önsértố } \\
\\
N=54 \\
\text { Átlag } \\
\text { (SD) }\end{array}$ & $\begin{array}{c}\text { Repetitív } \\
\text { önsértố } \\
N=183 \\
\text { Átlag } \\
\text { (SD) }\end{array}$ & $\begin{array}{l}\text { A csoportok közötti } \\
\text { különbséget jelzô } \\
\text { próbastatisztika }\end{array}$ & Cohen-d \\
\hline $\begin{array}{l}\text { Önsértés intraperszo- } \\
\text { nális funkciói }\end{array}$ & $4,48(3,82)$ & $6,79(4,18)$ & $\mathrm{t}_{(235)}=3,636^{* * *}$ & 0,58 \\
\hline $\begin{array}{l}\text { Önsértés interperszo- } \\
\text { nális funkciói }\end{array}$ & $6,41(6,21)$ & $7,20(5,10)$ & $\mathrm{t}_{(235)}=0,949$ & 0,14 \\
\hline Magányosság $^{+}$ & $2,79(0,66)$ & $2,46(0,88)$ & $\mathrm{t}_{(306)}=3,510 * *$ & 0,42 \\
\hline SDQ összprobléma & $13,54(4,76)$ & $16,71(5,49)$ & $\mathrm{t}_{(306)}=4,675^{* * *}$ & 0,62 \\
\hline $\begin{array}{l}\text { SDQ internalizáló } \\
\text { tünetek }\end{array}$ & $7,29(3,53)$ & $9,01(3,78)$ & $\mathrm{t}_{(306)}=3,640 * * *$ & 0,47 \\
\hline $\begin{array}{l}\text { SDQ externalizáló } \\
\text { tünetek }\end{array}$ & $6,25(2,80)$ & $7,69(3,16)$ & $\mathrm{t}_{(306)}=3,679 * * *$ & 0,48 \\
\hline SDQ proszocialitás & $7,80(1,69)$ & $7,64(1,93)$ & $\mathrm{t}_{(306)}=0,666$ & 0,09 \\
\hline DERS-16 össz & $42,54(11,14)$ & $49,75(13,74)$ & $\mathrm{t}_{(306)}=4,633 * * *$ & 0,58 \\
\hline SCRS össz & $26,57(6,19)$ & $29,86(7,04)$ & $\mathrm{t}_{(306)}=3,766^{* * *}$ & 0,50 \\
\hline AFQ-Y8 össz & $13,19(5,20)$ & $16,44(5,69)$ & $\mathrm{t}_{(306)}=4,570 * * *$ & 0,58 \\
\hline
\end{tabular}

Megjegyzés: $* p<0,05 ; * *<0,01 ; * * * p<0,0001$. A hatásméret-mutató (Cohen-d) értékeit Cohen (1992) alapján az alábbiak szerint értelmeztük: 0,20: kis hatás, 0,50: közepes hatás, 0,80: nagymértékú hatás. Dôlttel szedve a közepes hatásméretek. SDQ = Képességek és Nehézségek Kérdôív. DERS-16 = Érzelemszabályozási Nehézség Kérdôív rövid változat. SCRS = Önkritikus Rumináció Kérdőív. AFQ-Y8 = Tapasztalati Elkerülés Kérdôív. $^{+}=$fordított skála.

6. táblázat. Különbözô önsértố csoportok összehasonlítása a felmért változók mentén a teljes mintában

\begin{tabular}{|l|c|c|c|c|l|}
\hline Változó & $\begin{array}{c}\text { Sohasem } \\
\text { önsértôk } \\
(\mathrm{N}=596) \\
\mathrm{M}(\mathrm{SD})\end{array}$ & $\begin{array}{c}\text { Korábban } \\
\text { önsértők } \\
\mathrm{N}=96) \\
\mathrm{M}(\mathrm{SD})\end{array}$ & $\begin{array}{c}\text { Aktuálisan } \\
\text { onsértők } \\
(\mathrm{N}=322) \\
\mathrm{M}(\mathrm{SD})\end{array}$ & $\begin{array}{c}\text { Statisztikai próba értéke } \\
(\mathrm{p}) ; \\
\text { hatásméret-mutató }\end{array}$ & $\begin{array}{c}\text { Csoportok } \\
\text { közötti kü- } \\
\text { lönbségek* }\end{array}$ \\
\hline Magányosság
\end{tabular}

Megjegyzés: *A jelzett csoportok közötti különbségek minimum $\mathrm{p}<0,05$ szinten szignifikánsak. $\mathrm{f}=$ hatásméret-mutató: $0,10=$ kis hatásméret; $0,25=$ közepes hatásméret; $\mathrm{f}=0,40$ erôs hatásméret $(\mathrm{Cohen}, 1988)$. $\mathrm{S}$ = Sohasem önsértôk, $\mathrm{K}=$ Korábban önsértôk, $\mathrm{A}=$ Aktuálisan önsértôk. SDQ = Képességek és Nehézségek Kérdőív. DERS-16 = Érzelemszabályozási Nehézség Kérdőív rövid változat. SCRS = Önkritikus Rumináció Kérdôív. AFQ-Y8 = Tapasztalati Elkerülés Kérdôív. ${ }^{+}=$fordított skála. 
ternalizáló pszichés tünetek, érzelemregulációs problémák, önkritikus rumináció és kognitív rugalmatlanság) mentén. Lényeges eredmény, hogy a sohasem önsértôk a két önsértố csoporthoz képest erôs hatásméret-mutatók mellett mindegyik pszichés nehézséget jelzó változó tekintetében szignifikánsan a legalacsonyabb értékeket képviselték. Az aktuálisan önsértố csoport szignifikánsan markánsabb összprobléma-pontszámot, internalizáló tüneteket és pszichés rugalmatlanságot jelzett a korábban önsértôkhöz képest is. Ezzel ellentétben a két önsértô csoport nem tért el a magányosságérzet, az externalizáló tünetek, az érzelemszabályozási nehézségek és az önkritikus rumináció tekintetében. Az önbevalláson alapuló proszociális viselkedés pedig mindhárom csoportban azonos szintet mutatott.

\section{MEGBESZÉLÉS}

Az Állítások az Önsértés Kapcsán Kérdôívet Klonsky és Glenn (2009) a nem öngyilkossági szándékkal történô önsértés részletes felmérésére dolgozta ki. Fontosnak tartottuk, hogy ezt a normatív populációkban is jól használható, az önsértést mint tünetet (NSSI) és nem mint szindrómát (NSSID) felmérô komplex önkitöltôs kérdôívet a hazai tesztállomány részévé tegyük. Ez azért is lényeges, mert bár számos tanulmány az NSSI-viselkedések növekvô előfordulását jelzi nem klinikai serdüló és fiatal felnôtt mintákban (Brunner és mtsai, 2014; Cipriano, Cella és Cotrufo 2017; Wester és mtsai, 2018), a nemzetközi szakirodalomban is kevés számú valid, megbízhatóan mérô, öszszetett NSSI-kérdōív található. Ráadásképpen ezen mérôeszközök pszichometriai mutatóinak tesztelése még a külföldi kutatásokban is hiányos.

Az Állítások az Önsértés Kapcsán Kérdôív magyar változatával (ISAS-HU) felmért 1015 középiskolás serdülô több mint 40\%-a legalább egyszer már végzett önsértést életében, közel 32\%-uk pedig ezt az elmúlt hónapban tette, azaz az aktuálisan önsértôk közé sorolható. A magas élet- és pontprevalencia-értékek az elmúlt évtized nemzetközi trendjeit (Brunner és mtsai, 2014; Cipriano és mtsai, 2017; Wester és mtsai, 2018) egyértelmúen megerôsítik. A serdülő és a posztadoleszcens korosztályban a legalább kipróbálásszintú önsértés majdnem minden második vagy harmadik kamaszt érinthet. A gyakoriság emelkedése a jelenség elmélyültebb vizsgálatának és a prevenció kiterjesztésének szükségességét igazolja. Egy 2020-ban publikált magyar felmérés (Horváth és mtsai, 2020) adataihoz képest a vizsgált serdülők körében 17\%-kal magasabb az önsértés életprevalencia-értéke. Ennek hátterében több tényezô is állhat. Jelen vizsgálat hatszor nagyobb mintaelemszámmal dolgozott, 14 budapesti és vidéki középiskola 9-12. évfolyamos tanulóit közel egyenlô arányban vonta be a felmérésbe. Az általunk használt kérdôív tisztán az NSSI felmérésére szolgál, egyéb önkárosító magatartásformát nem azonosít. Az NSSI-t továbbá az ISAS-HU kérdőív összetettségében, több szempont szerint ragadta meg. Horváth és munkatársai (2020) 16 önsértố viselkedésforma puszta elôfordulását mérték fel a DSHI-kérdôívvel 161 budapesti középiskolás körében 2015 és 2017 között. Elképzelhetô, hogy a vizsgálatunkban megmutatkozó NSSI-gyakoriság részben az NSSI-jelenség növekedési trendjeit is leképezi. Végül kiemeljük, hogy vizsgálatunkban mind élettartam-, mind pontprevalencia-értékeket megragadtunk az árnyaltabb NSSI-feltárás érdekében. 
Megjegyezzük azonban azt is, hogy azon serdülók kétharmada, akik életük során beszámoltak önsértésrôl, több mint 10 önsértési epizódot jeleztek mintánkban. Ôket ún. "repeptitív" vagy "ismétlô" önsértôkként (Gratz és mtsai, 2015) tarthatjuk számon. Kutatásunkban a lányok almintájában összehasonlítottuk a kipróbáló és a repetitív önsértôk pszichés állapotát. A repetitív önsértôk egyértelmúen több mentális betegségtünetet és érzelemszabályozási problémát jeleztek: mind a hangulati élet, mind a magatartás terén konfliktusosabb állapotokat élnek meg. Érzelmeik szabályozásában pedig a maladaptívnak tekinthetô formák - így a fokozott önkritikusság, az érzelmek elnyomása, illetve a negatív érzelmek kapcsán megjelenô kognitív és viselkedésszabályozási problémák - dominálnak. Mindennek nyomán az önsértés motivációjában felerôsödhet az intraperszonális motívumok dominanciája: a repetitív önsértốk mintánkban inkább használják az önsértést érzelmeik szabályozására, mint a kipróbáló önsértôk. Ráadásul a repetitív önsértôk a kipróbálókhoz képest átlagosan magasabb tapasztalati elkerülést jeleztek, és a klinikai szintû neurotikus folyamatokra is veszélyeztetettebbek (Renshaw, 2017). Mindez jól beleilleszthetô az önsértés egyik folyamatmodelljének, a Tapasztalati Elkerülés Modellnek (Chapman és mtsai, 2006) a keretrendszerébe. A modell szerint ugyanis az érzelemszabályozásban jelentkezô problémák rosszabb distressztúrô képességhez és mentális egészséghez vezetnek, aminek talaján az erôteljesebb érzelmek éppen azért válthatnak ki önsértô viselkedésformákat, mert a személy - maladaptív módon - azokkal próbálja az ôt elöntô averzív affektusokat csökkenteni (Chapman és mtsai, 2006). További, longitudinális elrendezésú kutatások tisztázhatják, hogy milyen hatótényezók játszhatnak szerepet abban, hogy az önsértést kipróbáló kamaszok közül kik „ragadnak bele” ebbe a viselkedésformába, azaz kik válnak repetitív önsértôkké, és mely tényezôk segíthetik az abból való kilábalást.

Kutatásunk is megerôsítette az önsértés szakirodalmában (pl. Bresin és Schoenleber, 2015) régóta jelzett összefüggést: a kamaszlányok veszélyeztetettebbek az önsértô viselkedésformák tekintetében. Ennek háttere lehet, hogy az önsértés rizikófaktoraként azonosított érzelemszabályozási nehézségek (pl. rumináció, tapasztalati elkerülés) és hangulati panaszok (pl. depresszív tünetek) (Bentley és mtsai, 2015; Brereton és McGlinchey, 2019) gyakoribbak a lányoknál (Nolen-Hoeksema, Larson és Grayson, 1999). Szintén a korábbi szakirodalmi adatokra rímel (Barrocas és mtsai, 2012), hogy a lányok körében a bőr megvágása, megkarmolása és az abba való belevésés gyakoribb, mint a fiúknál. Míg a fiúk körében önmaguk megütése vagy valamely testrészük beütése gyakoribb a lányokhoz képest. A jellemzô önsértési módokban megjelenô nemi különbségek pszichológiai, motivációs hátterét erre fókuszáló további kutatások tisztázhatják. Ugyanakkor azt leszögezhetjük, hogy a nôk valószínúbben vesznek részt olyan önsértési formákban, melyekben a vér/vérzés is szerepet játszik (vágás, karmolás) (Bresin és Schoenleber, 2015; Sornberger, Heath, Toste és McLouth, 2012), de olyan önsértési formákban is, melyekhez vérzés nem kapcsolódik (pl. hajkitépés, csípés) (Bresin és Schoenleber, 2015). A vér látványának a szerepe az önsértésben és az önsértésben mutatkozó nemi különbségek tekintetében még tisztázatlan (Glenn és Klonsky, 2011). Általánosságban is, további kutatások szükségesek az NSSI-módokban mutatkozó nemi eltérések pszichodinamikai magyarázatára. A leggyakoribb önsértési mód mindkét nem esetében a sebek gyógyulásának megakadályozása volt, míg a legritkább valamilyen veszélyes anyag lenyelése. Elôbbi összefüggésben lehet azzal, hogy 
ennek az önsértési módnak az esetében vehetô észre a legkevésbé a szándékos önsértés a környezet számára. Itt jegyezzük meg, hogy a kamaszok többsége azt jelezte egy, az önsértéssel kapcsolatos aggodalmak felmérését célzó kérdésünk kapcsán, hogy a leginkább attól tart, hogy a környezetük észreveszi az önsértés jeleit. A veszélyes anyag fogyasztásának ritkasága annak invazív és drasztikus jellegével kapcsolódhat össze. Ehhez köthetô az is, hogy a veszélyes anyag lenyelése inkább az öngyilkossági kísérletekkel asszociálódik (WHO, 2019).

Az NSSI demográfiai jellemzôi között meg kell említenünk azt is, hogy - hasonlóképpen, mint korábbi tanulmányokban (pl. Glenn és Klonsky, 2009; Kostić, Žikić, Stankovic és Nikolić, 2019) - a vizsgálatunkban részt vevô kamaszok legtöbbje 12 és 15 éves kora közé tette az önsértés elsô megjelenését. Az, hogy az elsô önsértési epizód elôfordulásának átlaga 12 éves korra tehetô, felveti az önsértés-prevenció általános iskola felsố tagozatos bevezetésének szükségességét. Ebben a folyamatban jelentôs szerephez juthat az önsértés kapcsán számos szempontot felmérô ISAS-HU, mely szúrô kérdőívként funkcionálhat a primer és a szekunder prevenció során.

A kérdôív második felének, az önsértés hátterében álló lehetséges motívumoknak a faktorelemzése megerôsítette az eredeti változat szerkezetét (Klonksy és Glenn, 2009). Egy markáns intraperszonális és egy interperszonális funkciókör rajzolódott ki (Klonsky és Glenn, 2009; Bildik és mtsai, 2013; Kortge és mtsai, 2013; Klonsky és mtsai, 2015; Kim és mtsai, 2019; Pérez és mtsai, 2020). Az intraperszonális faktort az önsértés érzelemszabályozó, önbüntetô, disszociációt megszüntetô és distresszt jelzô motivációi építik fel. Ezek mindegyike az önsértés olyan motivációját mutatja fel, mely az elviselhetetlen érzelmi élmények kezelésében próbál segíteni. Ezek az eredmények megerôsítik az önsértés Négy Funkció Modelljének (Nock és Prinstein, 2004) automatikus (intraperszonális) negatív funkciókörének érvényességét. Az eredeti modelltôl (Klonsky és Glenn, 2009) az ISAS-HU egy tekintetben azonban eltér: az önsértés öngyilkossági gondolatokat megelôzó funkciója ugyanis tisztán az interperszonális faktorra töltôdött. Ennek lehetséges magyarázataként tarthatjuk számon, hogy serdülókorban az öngyilkossági gondolatokhoz gyakran társulnak a közeli családtagok és barátok tettre adott reakcióit elôvételezô, sokszor búntudattal átitatott fantáziák. A kamaszok ennek nyomán az öngyilkossági gondolatokhoz interperszonális aspektusokat köthetnek, ezzel az öngyilkosági gondolatokat elnyomó önsértéshez pedig kapcsolati érték kötődhet. Az ISAS-HU interperszonális motívum faktora így az alábbi, önsértésre okot adó területeket összegzi: öngyilkossági gondolatok megelőzése, személyközi határok szabályozása, önmagáról való gondoskodás, szenzoros élménykeresés, a kortársakhoz való kötôdés, interperszonális figyelem kiváltása, szívósság és autonómia, valamint bosszú kifejezése.

Ugyanakkor fontos eredmény, hogy a fiúk almintájában minden alskála erôsen kötôdik az interperszonális faktorhoz, illetve több alskála mindkét faktorra hasonlóképpen súlyozódik. Mindez felveti a mérôeszköz faktorstruktúrájának nemi különbségét, ezzel pedig azt, hogy más tartalma van az intraperszonális és az interperszonális önsértô motivációknak a két nem esetében - legalábbis kamaszkorban. A fiúk körében az önsértés mindegyik motivációs faktora az interperszonális háttérmechanizmusokhoz (is) kapcsolódik. A fiúk alacsony mintabeli száma miatt azonban körükben a faktorszerkezet további tesztelésétôl el kellett tekintenünk. Mindezt késôbbi - harmonikus 
fiú-lány arányt felmutató - vizsgálatok segíthetnek tisztázni. A faktorszerkezetre vonatkozó vizsgálataink azonban két szempontból is elôremutatóak. Tudomásunk szerint ugyanis ESEM-elemzést, mely a faktorszerkezet realisztikusabb, árnyaltabb leírását adja, eddig nem végeztek az ISAS kapcsán a szakirodalomban. Másrészt eddig nem tesztelték a kérdőív faktorszerkezetének esetleges nemi eltéréseit, annak lehetôségére eredményeink mutattak rá.

A fentiek miatt a lányok mintájára szorítkozva feltártuk a két kirajzolódó önsértés motivációkör kapcsolatrendszerét más felmért változókkal. Elvárásainknak megfelelốen az önsértés intraperszonális motivációi a magányossággal, a pszichés problémákkal és az érzelemreguláció nehézségeivel kapcsolódtak össze. Mindez tovább erôsíti a Tapasztalati Elkerülés Modell (Chapman és mtsai, 2006) érvényességét: a maladaptív, rugalmatlan érzelemszabályozás és a támogató (kor) társkapcsolatok hiánya rosszabb mentális állapothoz vezethet, ami felerôsítheti az önsértést aktiváló intraperszonális motívumokat. A folyamat egy idô után öngerjesztô lehet. Az intraperszonális okokon alapuló önsértés mint maladaptív érzelemregulációs mód (Chapman és mtsai, 2006) tovább fokozza a rossz érzelemszabályozást, a pszichés tüneteket, és a környezettôl is elszigetel. Utóbbi jelenséget erôsíti, hogy mintánk önsértô résztvevôinek közel kétharmada egyedül volt, amikor önsértést végzett.

A teljes mintán azt is feltérképeztük, hogy a sohasem, a korábban és a jelenleg önsértôk között milyen különbségek vannak a mentális egészség tekintetében. A legjobb pszichés állapottal a sohasem önsértôk írhatók le, míg az aktuálisan önsértôk jellemezhetôk a legrosszabb mentális státusszal. Körükben magas a neurotikus tünetek száma, és ôk igyekeznek leginkább távol tartani magukat belsố állapotaiktól, így érzelmeiktôl, emlékeiktôl, gondolataiktól. A korábban és az aktuálisan önsértôk azonban hasonló értékeket mutattak a magányérzés, az externalizáló tünetek, az érzelemszabályozási nehézségek és az önkritikus rumináció tekintetében. Annak tisztázása további kutatások feladata, hogy a már nem önsértố kamaszoknak mi segített eltávolodni az önsértéstôl, ha bizonyos érzelemregulációs problémák még mindig jellemzôek rájuk. További kutatási cél lehet azoknak a moderátorváltozóknak az azonosítása is, melyek az érzelemszabályozásban mutatkozó nehézségek és azok lehetséges kimenetelei (pl. önsértés és/vagy internalizáló problémák és/vagy externalizáló problémák) között közvetíthetnek.

\section{Korlátok}

Vizsgálatunk legfőbb limitációja a kamaszfiúk viszonylag alacsony részvételi aránya. A további kutatásokban fontos lenne törekedni a kiegyensúlyozott nemi megoszlásra. Ez abban is segítene, hogy a kipróbáló és a repetitív módon önsértést folytató kamaszok jellemzôinek esetleges nemi különbségeit is tesztelhessük.

Kutatásunkban általánosságban véve sine morbo kamasz populációt szólítottunk meg. Ugyanakkor lehetséges, hogy abban olyan középiskolás kamaszok is részt vettek, akik korábban vagy a kérdőívcsomag felvételének idôpontjában pszichés zavarral küzdöttek. Etikai okok miatt pszichológiai/pszichiátriai és ezzel összefüggésben gyógyszeres kezelésre nem kérdeztünk rá. Az internalizáló és externalizáló pszichés tünetek 
felmérésével és az elemzésekbe való bevonásukkal kívántuk a mentális egészség szintjét letapogatni. Vizsgálatunk további korlátja, hogy a bevezetett kérdôív funkcióskálájának konvergens validitását csak a lányok mintáján tudtuk tesztelni. Ez az adaptációs folyamat gyenge pontja, így további - nagy mintás - kutatásokban fontos lesz azt fiúk/ férfiak körében is elemezni. Kiemeljük továbbá, hogy az ISAS-HU intraperszonális és interperszonális faktora közötti gyenge korreláció arra utal, hogy azok egymástól független faktorok. A validáció során alkalmazott kérdőívek az intraperszonális folyamatokat mérik fel, kevéssé az interperszonális folyamatokat, ennek következtében az ISAS-HU intraperszonális funkciófaktorának konvergens validitását tudtuk ellenôrizni. Az intraperszonális faktortól függetlenül viselkedô interperszonális faktor validitásának tesztelésére további vizsgálatok szükségesek.

Végül hátrányként tarthatjuk számon a vizsgálat keresztmetszeti elrendezését, amely ok-okozati kapcsolatok feltárását nem tette lehetôvé. Hasonlóképpen módszertani negatívumént értékelhetjük, hogy a kamaszok - bár az iskolai személyzet jelenléte nélkül - az iskolában, kortársaik körében töltötték ki a kérdőívcsomagot. Mindez a téma fokozott érzékenysége és a társas kívánatosságnak való megfelelés miatt megnövelhette a nem teljesen ôszinte válaszok számát.

\section{KÖVETKEZTETÉSEK}

Eredményeink alapján az Állítások az Önsértés Kapcsán Kérdôív magyar változata (ISAS-HU) pszichometriailag jól múködő, a nem szuicidális önsértést számos szempontból könnyen és gyorsan felmérô összetett mérôeszköz. Ezen tulajdonságai alapján mind nagy mintás vizsgálatokban, mind egyéni konzultációs helyzetekben megbízhatóan alkalmazható.

\section{KÖSZÖNETNYILVÁNÍTÁS}

Reinhardt Melindát a Nemzeti Kutatási, Fejlesztési és Innovációs Hivatal (NKFIH) a PD 128332 számmal elnyert pályázat keretében támogatja. Kökönyei Gyöngyi a Nemzeti Kutatási, Fejlesztési és Innovációs Hivatal (NKFIH) FK 128614 számú pályázatának keretében, illetve a Nemzeti Agykutatási Program (2017-1.2.1-NKP-2017-00002) keretében részesül támogatásban. Urbán Róbertet a Nemzeti Kutatási, Fejlesztési és Innovációs Hivatal (NKFIH) TKP2020-IKA-05 számú Tématerületi Kiválósági Programja támogatja.

\section{IRODALOM}

American Psychiatric Association (2013). Diagnostic and statistical manual of mental disorders: DSM-5. Washington, DC: American Psychiatric Association.

Andover, M. S., \& Gibb, B. E. (2010). Non-suicidal self-injury, attempted suicide, and suicidal intent among psychiatric inpatients. Psychiatry Research, 178(1), 101-105. 
Baetens, I., Claes, L., Muehlenkamp, J., Grietens, H., \& Onghena, P. (2012). Differences in psychological symptoms and self-competencies in non-suicidal self-injurious Flemish adolescents. Journal of Adolescence, 35, 753-759.

Barrocas, A. L., Hankin, B. L., Young, J. F., \& Abela, J. R. (2012). Rates of nonsuicidal self-injury in youth: age, sex, and behavioral methods in a community sample. Pediatrics, 130(1), $39-45$.

Batey, H., May, J., \& Andrade, J. (2010). Negative intrusive thoughts and dissociation as risk factors for self-harm. Suicide and Life-Threatening Behavior, 40(1), 35-49.

Bentley, K. H., Cassiello-Robbins, C. F., Vittorio, L., Sauer-Zavala, S., \& Barlow, D. H. (2015). The Association between nonsuicidal self-injury and the emotional disorders: A meta-analytic review. Clinical Psychology Review, 37, 72-88.

Bildik, T., Somer, O., Kabukcu Basay, B., Basay, O., \& Ozbaran, B. (2013). The validity and reliability of the Turkish version of the Inventory of Statements About Self-injury. Turkish Journal of Psychiatry, 24(1), 49-57.

Bjureberg, J., Ljótsson, B., Tull, M. T., Hedman, E., Sahlin, H., Lundh, L-G., et al. (2016). Development and validation of a brief version of the Difficulties in Emotion Regulation Scale: The DERS-16. Journal of Psychopathology and Behavioral Assessment, 38, 284-296.

Brackman, E. H., \& Andover, A. S. (2017). Non-suicidal self-injury. In D. McKay, D. S. Abramowitz \& E. A. Storch (Eds), Treatments for Psychological Problems and Syndromes (pp. 328-344). New Jersey: Wiley-Blackwell.

Brereton, A., \& McGlinchey, E. (2019). Self-harm, emotion regulation, and experiential avoidance: A systematic review. Archives of Suicide Research. Advance online publication. DOI: https://doi.org/10.1080/13811118.2018.1563575

Bresin, K., \& Schoenleber, M. (2015). Gender differences in the prevalence of nonsuicidal self-injury: a meta-analysis. Clinical Psychology Review, 38, 55-64.

Brown, R. C., \& Plener, P. L. (2017). Non-suicidal self-injury in adolescence. Current Psychiatry Reports, 19(3), 20.

Brunner, R., Kaess, M., Parzer, P., Fischer, G., Carli, V., \& Hoven, C. W., et al. (2014). Life-time prevalence and psychosocial correlates of adolescent direct self-injurious behavior: A comparative study of findings in 11 European countries. Journal of Child Psychology and Psychiatry, $55,(4), 337-348$.

Chapman, A. L., Gratz, K. L., \& Brown, M. Z. (2006). Solving the puzzle of deliberate self-harm: The experiential avoidance model. Behaviour Research and Therapy, 44, 371-394.

Cipriano, A., Cella, S., \& Cotrufo, P. (2017). Nonsuicidal self-injury: A systematic review. Frontiers in Psychology, 8, 1-14.

Claes, L., \& Vandereycken, W. (2007). The Self-Injury Questionnaire-Treatment Related (SIQ-TR): Construction, reliabilty, and validity in a sample of female eating disorder patients. In P. M. Goldfarb (Ed.), Psychological tests and testing research trends (pp. 111-139). New York: Nova Science Publishers.

Cohen, J. (1988). Statistical Power Analysis for the Behavioral Sciences. New York, NY: Routledge Academic.

Cohen, J. (1992). A power primer. Psychological Bulletin, 112(1), 155-159.

Favazza, A. (1986). Self-harm behavior survey. Columbia, MI: Author.

Finney, S. J., \& DiStefano, C. (2006). Nonnormal and categorical data in structural equation modeling. In G. R. Hancock \& R. O. Mueller (Eds), Structural equation modeling: A second course (pp. 269-314). Greenwich, CT: Information Age.

Fox, K. R., Franklin, J. C., Ribeiro, J. D., Kleiman, E. M., Bentley, K. H., \& Nock, M. K. (2015). Meta-analysis of risk factors for nonsuicidal self-injury. Clinical Psychology Review, 42, $156-167$. 
Glenn, C. R., Klonsky, E. D. (2009). Social context during non-suicidal self-injury indicates suicide risk. Personality and Individual Differences, 46, 25-29.

Glenn, C. R., \& Klonsky, E. D. (2011). Prospective prediction of nonsuicidal self-injury: A 1-year longitudinal study in young adults. Behavior Therapy, 46, 25-29.

Glenn, J. J., Michel, B. D., Franklin, J. C., Hooley, J. M., \& Nock, M. K. (2014). Pain analgesia among adolescent self-injurers. Psychiatry Research, 220, 921-926.

Goodman, R., Meltzer, H., \& Bailey, V. (1998). The Strengths and Difficulties Questionnaire: A pilot study on the validity of the self-report version. European Child \& Adolescent Psychiatry, $7(3), 125-130$.

Gratz, K. L. (2001). Measurement of deliberate self-harm: Preliminary data on the Deliberate Self-Harm Inventory. Journal of Psychopathology and Behavioral Assessment, 23, 253-263.

Gratz, K. L., \& Roemer, L. (2004). Multidimensional assessment of emotion regulation and dysregulation: development, factor struture, and initial validation of the Difficulties in Emotion Regulation Scale. Journal of Psychopathology and Behavioral Assessment, 26, 41-54.

Gratz, K. L., Dixon-Gordon, K. L., Chapman, A. L., \& Tull, M. T. (2015). Diagnosis and characterization of DSM-5 Nonsuicidal Self-Injury Disorder using the Clinician-Administered Nonsuicidal Self-Injury Disorder Index. Assessment, 22, 527-539.

Greco, L. A., Lambert, W., \& Baer, R. A. (2008). Psychological Inflexibility in Childhood and Adolescence: Development and Evaluation of the Avoidance and Fusion Questionnaire for Youth. Psychological Assessment, 20, 93-102.

Horváth, L. O., Gyốri, D., Komáromy, D., Mészáros, G., Szentiványi, D., \& Balázs, J. (2020). Non-suicidal self-injury and suicide: The role of life events in clinical and non-clinical populations of adolescents. Frontiers in Psychiatry, 11, 370.

Im, S., \& Kahler, J. (2020). Evaluating the empirical evidence for three transdiagnostic mechanisms in anxiety and mood disorders. The Journal of General Psychology. DOI: http://dx.doi.o $\mathrm{rg} / 10.1080 / 00221309.2020 .1828252$

International Society for the Study of Self-Injury (2018, May). What is self-injury? Letöltve 2020. 12. 10-én: https://itriples.org/about-self-injury/what-is-self-injury

Jacobson, C. M., \& Gould, M. (2007). The epidemiology and phenomenology of non-suicidal self-injurious behavior among adolescents: A critial review of the literature. Archives of Suicide Research, 11(2), 129-147.

Kim, S., Kim, Y., \& Hur, W. (2019). Non-suicidal self-injury among Korean Young adults: A validation of the Korean version of the Inventory of Statements About Self-Injury. Psychiatry Investigation, 16(4), 270-278.

Klonsky, E. D. (2007). The functions of deliberate self-injury: A review of the evidence. Clinical Psychology Review, 27, 226-239.

Klonsky, E. D., \& Glenn, C. R. (2009). Assessing the Functions of Non-suicidal Self-injury: Psychometric Properties of the Inventory of Statements About Self-Injury (ISAS). Journal of Psychopathology and Behavioral Assessment, 31(3), 215-219.

Klonsky, E. D., Victor, S. E., \& Saffer, B. Y. (2014). Non-suicidal self-injury: What we know, and what we need to know. The Canadian Journal of Psychiatry, 59, 565-568.

Klonksy, E. D., Glenn, C. R., Styer, D. M., Olino, T. M., \& Washburn, J. J. (2015). The functions of nonsuicidal self-injury: converging evidence for a two-factor structure. Child and Adolescent Psychiatry and Mental Health, 9, 44.

Kortge, R., Meade, T., \& Tennant, A. (2013). Interpersonal and intrapersonal functions of deliberate self-harm (DSH): a psychometric examination of the Inventory of Statements About Self-Injury (ISAS) scale. Behaviour Change, 30, 24-35. 
Kostić, J., Žikić, O., Stankovic, M., \& Nikolić, G. (2019). Nonsuicidal self-injury among adolescents in South Eastern Serbia. International Journal of Pediatrics and Adolescent Medicine, 6, 131-134.

Kökönyei, Gy., Urbán, R., Reinhardt, M., Józan, A., \& Demetrovics, Zs. (2014). The Difficulties in Emotion Regulation Scale: Factor structure in chronic pain patients. Journal of Clinical Psychology, 70, 589-600.

Liu, R. T., Frazier, E. A., Cataldo, A. M., Simon, V. A., Spirito, A., \& Prinstein, M. J. (2014). Negative life events and non-suicidal self-injury in an adolescent inpatient sample. Archives of Suicide Research, 18(3), 251-258.

Muehlenkamp, J. J., Claes, L., Havertape, L., \& Plener, P. L. (2012). International prevalence of adolescent non-suicidal self-injury and deliberate self-harm. Child and Adolescent Psychiatry and Mental Health, 6, 10.

Muthén, L. K., \& Muthén, B. O. (1998-2017). Mplus: Statistical analysis with latent variables. User's guide. Los Angeles, CA: Muthén \& Muthén.

Nock, M. K., \& Mendes, W. B. (2008). Psychological arousal, distress tolerance, and social problem-solving deficits among adolescent self-injurers. Journal of Consulting and Clinical Psychology, 76(1), 28-38.

Nock, M. K., \& Prinstein, M. J. (2004). A functional approach to the assessment of self-mutilative behavior. Journal of Consulting and Psychology, 72, 885-890.

Nolen-Hoeksema, S., Larson, J., \& Grayson, C. (1999). Explaining the gender difference in depressive symptoms. Journal of Personality and Social Psychology, 77(5), 1061-1072.

Pérez, S., García-Alandete, J., Cañabate, M., \& Marco, J. H. (2020). Confirmatory factor analysis of the Inventory of Statement About Self-injury in a Spanish clinical sample. Journal of Clinical Psychology, 76, 102-117.

Reinhardt, M., Drubina, B., Horváth, Zs., \& Kökönyei, Gy. (2020). A nem öngyilkossági szándékkal történô önsértés komplex felmérése - a Kezelésközpontú Önsértés Kérdôív (SIQ-TR) magyar adaptációja. Mentálhigiéné és Pszichoszomatika, 21(2), 121-175.

Renshaw, T. L. (2017). Screening for psychological inflexibility: Initial validation of the Avoidance and Fusion Questionnaire for Youth as a school mental health screener. Journal of Psychoeducational Assessment, 35(5), 482-493.

Rodham, K., Hawton, K., \& Ewans, E. (2004). Reasons for deliberate self-harm: Comparison of self-poisoners and self-cutters in a community sample of adolescents. Journal of the American Academy of Child \& Adolescent Psychiatry, 43, 80-87.

Sansone, R. A., \& Sansone, L. A. (2010). Measuring self-harm behavior with the Self-Harm Inventory. Psychiatry, 7(4), 16-20.

Scoliers, G., Portzky, G., Madge, N., Hewitt, A., Hawton, K., \& De Wilde, E. J., et al. (2009). Reasons for adolescent deliberate self-harm: A cry of pain and/or a cry for help? Findings from the Child \& Adolescent Self-Harm in Europe (CASE) Study. Social Psychiatry and Psychiatric Epidemiology, 44, 601-607.

Smart, L. M., Peters, J. R., \& Baer, R. (2016). Development and validation of a measure of self-critical rumination. Assessment, 23(3), 321-332.

Sornberger, M. J., Heath, N. L., Toste, J. R., \& McLouth, R. (2012). Nonsuicidal self-injury and gender: Patterns of prevalence, methods, and locations among adolescents. Suicide and Life Threatening Behavior, 42, 266-278.

Swannell, S. V., Martin, G. E., Page, A., Hasking, P., \& St John, N. J. (2014). Prevalence of nonsuicidal self-injury in nonclinical samples: systematic review, meta-analysis and meta-regression. Suicide and Life-Threatening Behavior, 44(3), 273-303. 
Szemenyei, E., Reinhardt, M., Szabó, E., Szabó, K. G., Urbán, R., Harvey, S. T., et al. (2020). Measuring Psychological Inflexibility in Children and Adolescents: Evaluating the Avoidance and Fusion Questionnaire for Youth. Assessment, 27(8), 1810-1820.

Taylor, P. J., Jomar, K., Dhingra, K., Forrester, R., \& Shahmalak, U. (2018). A meta-analysis of the prevalence of different functions of non-suicidal self-injury. Journal of Affective Disorders, 227, 759-769.

Turi, E., Tóth, I., \& Gervai, J. (2011). A Képességek és Nehézségek Kérdôív (SDQ-Magy) további vizsgálata nem-klinikai mintán, fiatal serdülő́k körében. Psychiatria Hungarica, 26, 415-426.

Washburn, J. J., Klonsky, E. D., Styer, D. M., Gebhardt, M., Juzwin, K. R., \& Aldridge, D. (2012). Short form of the Inventory of Statements About Self-Injury. Poster presentation at the 7th annual meeting of the International Society for the Study of Self-Injury. Chapel Hill, NC.

Wester, K., Trepal, H., \& King, K. (2018). Nonsuicidal self-injury: Increased prevalence in engagement. Suicide and Life-Threatening Behavior, 48(6), 690-698.

World Health Organization (WHO) (2001). Declaration of Helsinki. Bulletin of the World Health Organization, 79(4), 373-374.

World Health Organization (WHO) (2019). Suicide. Letöltve 2020. 12. 17-én: https://www.who. $\mathrm{int} /$ news-room/fact-sheets/detail/suicide

Zetterqvist, M. (2015). The DSM-5 diagnosis of nonsuicidal self-injury disorder: a review of the empirical literature. Child and Adolescent Psychiatry and Mental Health, 9, 31. 


\section{FÜGGELÉK}

\section{Állítások az Önsértés Kapcsán Kérdő́iv (ISAS-HU)}

Az önsértô viselkedés a saját test felületének különbözô módú, szándékos, önmagunk által okozott megsértését jelenti (pl. saját magunk megvágása, megégetése), de mindez öngyilkossági szándék nélkül történik (azaz, aki ezt teszi, nem akar meghalni).

Ez a kérdőív különféle szándékos önsértô viselkedésekrôl kérdez. Kérünk, csak akkor jelölj be egy viselkedésformát, ha azt szándékosan (azaz tudatosan), de nem öngyilkossági szándékkal tetted (azaz nem akartál meghalni).

1. Kérjük, becsüld meg, hogy az életed folyamán hányszor sértetted meg önmagad szándékosan (azaz tudatosan) az alább felsorolt önsértési módokkal (pl. 0-szor, 10-szer, 100-szor, 500-szor).

megvágtad magad megharaptad magad megégetted magad

belevéstél valamit a bórödbe belecsíptél magadba (erôsen) kitépted a hajad Más forma (ha volt ilyen, írd ide): nagyon erôsen/mélyen megkarmoltad magad beütötted vagy megütötted magad megakadályoztad a sebeid gyógyulását (pl. azzal, hogy letépted a vart a sebedrôl) durva felületnek dörzsölted a bőrödet túvel megszúrtad magad veszélyes anyagot nyeltél le , gyakorisága:

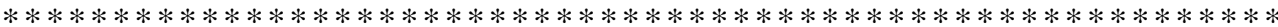

Fontos: Ha a fent felsorolt viselkedések közül egyet vagy többet csináltál már, kérjük, folytasd a kérdőív kitöltését. Amennyiben nem csináltad a fentiek közül egyiket sem, akkor ezt a kérdóívet nem kell tovább kitöltened.

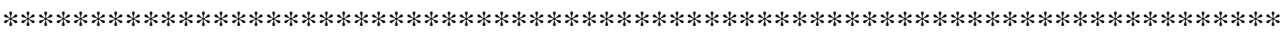

2. Ha úgy érzed, hogy van az önsértésnek egy olyan formája, amelyik a leginkább jellemzô rád (a legtöbbször csinálod/csináltad), kérjük, karikázd be a fentebbi listából azt a viselkedést vagy viselkedéseket.

3. Hány éves voltál, amikor elôször sértetted meg magad valamilyen módon a fentiek közül? éves voltam

Mikor sértetted meg magad legutoljára valamilyen módon a fentiek közül?

(ha nem tudod pontosan, akkor írj egy megközelítő dátumot: év, hónap, nap) 
4. Éreztél-e fizikai (testi) fájdalmat az önsértés közben? Karikázd be az alábbi lehetôségek közül!

$$
\text { IGEN NÉHA NEM }
$$

5. Egyedül voltál, amikor az önsértést csináltad? Karikázd be válaszod az alábbi lehetôségek közül!
IGEN
NÉHA
NEM

6. Általában mennyi idố telik el aközött, hogy késztetést érzel az önsértésre és aközött, hogy meg is teszed? Karikázd be válaszod az alábbi lehetôségek közül!
kevesebb mint 1 óra
1-3 óra
3-6 óra
6-12 óra
12-24 óra
több mint egy nap

7. Szeretted volna valaha / szeretnéd-e abbahagyni az önsértést? Karikázd be válaszod az alábbi lehetôségek közül!

\section{IGEN}

NEM

Ez a mérôeszköz azért készült, hogy jobban megérthessük a nem öngyilkossági szándékkal történő önsértés során tapasztaltakat. Lentebb olyan állításokat találsz, melyek talán jellemzôek az önsértéssel kapcsolatos tapasztalataidra, talán nem. Kérjük, jelöld azokat az állításokat, melyek a leginkább jellemzôek rád:

- Karikázd be a 0-át, ha az állítás egyáltalán nem jellemző rád.

- Karikázd be az 1-est, ha az állítás valamennyire jellemző rád.

- Karikázd be a 2-est, ha az állítás nagyon jellemzó rád.

$$
0=\text { nem jellemzô } \quad 1 \text { = valamennyire jellemzô } \quad 2 \text { = nagyon jellemzô }
$$

\begin{tabular}{|c|c|c|c|}
\hline Amikor önsértést végzek, akkor azáltal... & \multicolumn{3}{|c|}{ Válasz } \\
\hline 1. ...lenyugtatom / megnyugtatom magam. & 0 & 1 & 2 \\
\hline 2. ..határt húzok magam és mások közé. & 0 & 1 & 2 \\
\hline 3. ...megbüntetem magam. & 0 & 1 & 2 \\
\hline $\begin{array}{l}\text { 4. ...egyfajta lehetôséget teremtek arra, hogy törôdjek magam- } \\
\text { mal (azáltal, hogy a sebeket ápolom). }\end{array}$ & 0 & 1 & 2 \\
\hline $\begin{array}{l}\text { 5. ...fájdalmat okozok magamnak, hogy megszüntessem a } \\
\text { tompultság/dermedtség érzését. }\end{array}$ & 0 & 1 & 2 \\
\hline $\begin{array}{l}\text { 6. ...nem érzek késztetést arra, hogy öngyilkosságot kíséreljek } \\
\text { meg. }\end{array}$ & 0 & 1 & 2 \\
\hline
\end{tabular}




\begin{tabular}{|c|c|c|c|}
\hline Amikor önsértést végzek, akkor azáltal... & \multicolumn{3}{|c|}{ Válasz } \\
\hline $\begin{array}{l}\text { 7. folyasmit csinálok, ami izgatottságot vagy vidámságot } \\
\text { okoz. }\end{array}$ & 0 & 1 & 2 \\
\hline 8. ...úgy érzem, hogy kapcsolódni tudok a kortársaimhoz. & 0 & 1 & 2 \\
\hline $\begin{array}{l}\text { 9. ‥tudtára adom másoknak az érzelmi fájdalmam mélysé- } \\
\text { gét. }\end{array}$ & 0 & 1 & 2 \\
\hline 10. ...láthatom, hogy vajon kibírom-e a fájdalmat. & 0 & 1 & 2 \\
\hline $\begin{array}{l}\text { 11. ...egy látható (testi) jelet hozok létre, hogy szörnyen érzem } \\
\text { magam. }\end{array}$ & 0 & 1 & 2 \\
\hline 12. ...visszavágok valakinek. & 0 & 1 & 2 \\
\hline ...bizonyítom az önállóságomat. & 0 & 1 & 2 \\
\hline $\begin{array}{l}\text { 14. ‥csökkentem azt az érzelmi nyomást, ami kialakult ben- } \\
\text { nem. }\end{array}$ & 0 & 1 & 2 \\
\hline 15. ...bizonyítom, hogy független vagyok másoktól. & 0 & 1 & 2 \\
\hline $\begin{array}{l}\text { 16. ...kifejezem a haragomat saját magam felé, amiért értékte- } \\
\text { len vagy buta vagyok. }\end{array}$ & 0 & 1 & 2 \\
\hline $\begin{array}{l}\text { 17. ..olyan testi sérülést okozok, amivel könnyebb foglalkozni, } \\
\text { mint az érzelmi szenvedéssel. }\end{array}$ & 0 & 1 & 2 \\
\hline $\begin{array}{l}\text { 18. ...megpróbálok érezni valamit (ami más, mint a semmi), } \\
\text { még akkor is, ha az testi fájdalom. }\end{array}$ & 0 & 1 & 2 \\
\hline $\begin{array}{l}\text { 19. …az öngyilkossági gondolataimra reagálok anélkül, hogy } \\
\text { valójában öngyilkosságot kísérelnék meg. }\end{array}$ & 0 & 1 & 2 \\
\hline $\begin{array}{l}\text { 20. } \begin{array}{l}\text {...szórakoztatom magam vagy másokat azzal, hogy valami } \\
\text { szélsôséges / extrém dolgot csinálok. }\end{array} \\
\end{array}$ & 0 & 1 & 2 \\
\hline $\begin{array}{l}\text { 21. ..összehangolódom másokkal / hasonlóvá válok a többiek- } \\
\text { hez. }\end{array}$ & 0 & 1 & 2 \\
\hline 22. ...gondoskodást vagy segítséget keresek másoktól. & 0 & 1 & 2 \\
\hline 23. ...bebizonyítom, hogy kemény vagy erôs vagyok. & 0 & 1 & 2 \\
\hline $\begin{array}{l}\text { 24. ..bebizonyítom magamnak, hogy az érzelmi fájdalmam va- } \\
\text { lóságos. }\end{array}$ & 0 & 1 & 2 \\
\hline ...bosszút állok másokon. & 0 & 1 & 2 \\
\hline $\begin{array}{l}\text { 26. ‥bebizonyítom, hogy nincs szükségem arra, hogy mások } \\
\text { segítségére támaszkodjak. }\end{array}$ & 0 & 1 & 2 \\
\hline $\begin{array}{l}\text { 27. ...csökkentem a szorongást, a csalódottságot, a haragot } \\
\text { vagy bármely más nyomasztó érzelmet. }\end{array}$ & 0 & 1 & 2 \\
\hline ...akadályt építek magam és mások közé. & 0 & 1 & 2 \\
\hline $\begin{array}{l}\text { 29. …arra reagálok, hogy boldogtalanságot vagy undort érzek } \\
\text { önmagammal kapcsolatban. }\end{array}$ & 0 & 1 & 2 \\
\hline $\begin{array}{l}\text { 30. W.lehetôséget teremtek arra, hogy a sérülésem kezelésére } \\
\text { koncentráljak, ami örömöt vagy kielégülést okoz. }\end{array}$ & 0 & 1 & 2 \\
\hline $\begin{array}{l}\text { 31. ...megbizonyosodom arról, hogy még élek, amikor már } \\
\text { úgy érzem, hogy nem is létezek, amikor már semmi sem } \\
\text { tûnik valóságosnak. }\end{array}$ & 0 & 1 & 2 \\
\hline
\end{tabular}




\begin{tabular}{|c|c|c|c|}
\hline Amikor önsértést végzek, akkor azáltal... & \multicolumn{3}{|c|}{ Válasz } \\
\hline 32. ...leállítom az öngyilkossági gondolataimat. & 0 & 1 & 2 \\
\hline $\begin{array}{l}\text { 33. ‥feszegetem a határaimat úgy, mintha ejtôernyôznék, vagy } \\
\text { más extrém sportot úznék. }\end{array}$ & 0 & 1 & 2 \\
\hline $\begin{array}{l}\text { 34. ...a barátságot vagy az odatartozást jelzem a barátaim vagy } \\
\text { a szeretteim felé. }\end{array}$ & 0 & 1 & 2 \\
\hline $\begin{array}{l}\text { 35. ...megakadályozom, hogy egy szerettem elhagyjon vagy } \\
\text { magamra hagyjon. }\end{array}$ & 0 & 1 & 2 \\
\hline ...bebizonyítom, hogy el tudom viselni a fizikai fájdalmat. & 0 & 1 & 2 \\
\hline ...kifejezésre juttatom az érzelmi szenvedésemet. & 0 & 1 & 2 \\
\hline ...megpróbálok megbántani valakit, aki közel áll hozzám. & 0 & 1 & 2 \\
\hline 39. ...megmutatom, hogy önálló/független vagyok. & 0 & 1 & 2 \\
\hline
\end{tabular}

Választható, hogy válaszolsz-e a következô kérdésre: Kérjük, fogalmazz meg olyan állításokat, melyekrôl úgy érzed, hogy a fentebb felsoroltaknál pontosabban megfogalmazzák, mi jellemzô rád, amikor önsértést végzel.

Választható, hogy válaszolsz-e a következô kérdésre: Kérjük, sorolj fel olyan állításokat, melyekrôl úgy érzed, hogy hozzá kellene tenni a fentebb felsoroltakhoz, még akkor is, ha nem feltétlenül vonatkoznak rád.

Az ISAS funkció skála hosszú változatának kiértékelése:

(1) Érzelemszabályozó funkció (1., 14., 27. tétel); (2) Személyközi határok szabályozása (2., 15., 28. tétel); (3) Önbüntetés (3., 16., 29. tétel); (4) Gondoskodás önmagáról (4., 17., 30. tétel); (5) Disszociáció megszüntetése/érzések generálása (5., 18., 31. tétel); (6) Öngyilkossági gondolatok megelôzzése (6., 19., 32. tétel); (7) Szenzoros élménykeresés (7., 20., 33. tétel); (8) Kötôdés a kortársakhoz (8., 21., 34. tétel); (9) Interperszonális figyelem kiváltása (9., 22., 35. tétel); (10) Szívósság kifejezése (10., 23., 36. tétel); (11) Distressz jelzése (11., 24., 37. tétel); (12) Boszszú kifejezése (12., 25., 38. tétel) és (13) Autonómia kifejezése (13., 26., 39. tétel).

\section{Az ISAS funkció skálájának rövid változata és kiértékelése}

\begin{tabular}{|c|c|c|c|}
\hline Amikor önsértést végzek, akkor azáltal... & \multicolumn{3}{|c|}{ Válasz } \\
\hline 1. ...határt húzok magam és mások közé. & 0 & 1 & 2 \\
\hline $\begin{array}{l}\text { 2. ...egyfajta lehetôséget teremtek arra, hogy törôdjek } \\
\text { magammal (azáltal, hogy a sebeket ápolom). }\end{array}$ & 0 & 1 & 2 \\
\hline $\begin{array}{l}\text { 3. ...fájdalmat okozok magamnak, hogy megszüntessem a } \\
\text { tompultság/dermedtség érzését. }\end{array}$ & 0 & 1 & 2 \\
\hline $\begin{array}{l}\text { 4. ...nem érzek késztetést arra, hogy öngyilkosságot kíséreljek } \\
\text { meg. }\end{array}$ & 0 & 1 & 2 \\
\hline ...úgy érzem, hogy kapcsolódni tudok a kortársaimhoz. & 0 & 1 & 2 \\
\hline 6. ...tudtára adom másoknak az érzelmi fájdalmam mélységét. & 0 & 1 & 2 \\
\hline ...láthatom, hogy vajon kibírom-e a fájdalmat. & 0 & 1 & 2 \\
\hline
\end{tabular}




\begin{tabular}{|c|c|c|c|}
\hline \multirow{2}{*}{$\begin{array}{l}\text { Amikor önsértést végzek, akkor azáltal... } \\
\begin{array}{l}\text { 8. . . egy látható (testi) jelet hozok létre, hogy szörnyen érzem } \\
\text { magam. }\end{array}\end{array}$} & \multicolumn{3}{|c|}{ Válasz } \\
\hline & 0 & 1 & 2 \\
\hline 9. ...visszavágok valakinek. & 0 & 1 & 2 \\
\hline $\begin{array}{l}\text { 10. ...csökkentem azt az érzelmi nyomást, ami kialakult } \\
\text { bennem. }\end{array}$ & 0 & 1 & 2 \\
\hline $\begin{array}{l}\text { 11. ...kifejezem a haragomat saját magam felé, amiért } \\
\text { értéktelen vagy buta vagyok. }\end{array}$ & 0 & 1 & 2 \\
\hline $\begin{array}{l}\text { 12. ...megpróbálok érezni valamit (ami más, mint a semmi), } \\
\text { még akkor is, ha az testi fájdalom. }\end{array}$ & 0 & 1 & 2 \\
\hline $\begin{array}{l}\text { 13. ...szórakoztatom magam vagy másokat azzal, hogy valami } \\
\text { szélsôséges / extrém dolgot csinálok. }\end{array}$ & 0 & 1 & 2 \\
\hline 14. ...gondoskodást vagy segítséget keresek másoktól. & 0 & 1 & 2 \\
\hline 15. ...bosszút állok másokon. & 0 & 1 & 2 \\
\hline $\begin{array}{l}\text { 16. ...bebizonyítom, hogy nincs szükségem arra, hogy mások } \\
\text { segítségére támaszkodjak. }\end{array}$ & 0 & 1 & 2 \\
\hline $\begin{array}{l}\text { 17. ...csökkentem a szorongást, a csalódottságot, a haragot } \\
\text { vagy bármely más nyomasztó érzelmet. }\end{array}$ & 0 & 1 & 2 \\
\hline 18. ....akadályt építek magam és mások közé. & 0 & 1 & 2 \\
\hline $\begin{array}{l}\text { 19. ... arra reagálok, hogy boldogtalanságot vagy undort érzek } \\
\text { önmagammal kapcsolatban. }\end{array}$ & 0 & 1 & 2 \\
\hline $\begin{array}{l}\text { 20. ...lehetôséget teremtek arra, hogy a sérülésem kezelésére } \\
\text { koncentráljak, ami örömöt vagy kielégülést okoz. }\end{array}$ & 0 & 1 & 2 \\
\hline 21. ...leállítom az öngyilkossági gondolataimat. & 0 & 1 & 2 \\
\hline $\begin{array}{l}\text { 22. ...feszegetem a határaimat úgy, mintha ejtôernyôznék, vagy } \\
\text { más extrém sportot úznék. }\end{array}$ & 0 & 1 & 2 \\
\hline $\begin{array}{l}\text { 23. ...a barátságot vagy az odatartozást jelzem a barátaim vagy a } \\
\text { szeretteim felé. }\end{array}$ & 0 & 1 & 2 \\
\hline 24. ...bebizonyítom, hogy el tudom viselni a fizikai fájdalmat. & 0 & 1 & 2 \\
\hline 25. ...kifejezésre juttatom az érzelmi szenvedésemet. & 0 & 1 & 2 \\
\hline 26. ...megmutatom, hogy önálló/független vagyok. & 0 & 1 & 2 \\
\hline
\end{tabular}

(1) Érzelemszabályozó funkció (10., 17. tétel); (2) Személyközi határok szabályozása (1., 18. tétel); (3) Önbüntetés (11., 19. tétel); (4) Gondoskodás önmagáról (2., 20. tétel); (5) Disszociáció megszüntetése/érzések generálása (3., 12. tétel); (6) Öngyilkossági gondolatok megelôzése (4., 21. tétel); (7) Szenzoros élménykeresés (13., 22. tétel); (8) Kötôdés a kortársakhoz (5., 23. tétel); (9) Interperszonális figyelem kiváltása (6., 14. tétel); (10) Szívósság kifejezése (7., 24. tétel); (11) Distressz jelzése (8., 25. tétel); (12) Bosszú kifejezése (9., 15. tétel) és (13) Autonómia kifejezése (16., 26. tétel). 


\title{
MEASURING NON-SUICIDAL SELF-INJURY AND ITS MOTIVATION AMONG ADOLESCENTS: HUNGARIAN ADAPTATION OF THE INVENTORY OF STATEMENTS ABOUT SELF-INJURY
}

\author{
REINHARDT, MELINDA - KÖKÖNYEI, GYÖNGYI - DRUBINA, BOGLÁRKA - \\ URBÁN, RÓBERT
}

Background and aims: Lifetime prevalence of non-suicidal self-injury (e.g., direct cutting or hitting the own body) is estimated between $18 \%$ and $40 \%$ in community adolescents samples. However, limited number of complex, non-suicidal self-injurious behavior screening questionnaires exist. Therefore, the main aim of our research was to introduce a detailed self-injury questionnaire, the Hungarian version of the Inventory of Statements About Self-Injury (ISAS-HU) into the Hungarian test system.

Methods: High school students ( $N=1015 ; 66.1 \%$ girls $(N=671)$; mean age was 16.81; $S D=1.42)$ filled out questionnaires on emotion regulation, mental health aspects, and self-injurious behaviours.

Results: Nearly $60 \%$ of the adolescents $(58.8 \%$; $N=597)$ have never, while $41.2 \%$ ( $N=418)$ have already engaged in self-harm at least once in their life. Thirty two percent of the whole sample $(N=322)$ engaged in self-harm in the previous month. Girls are at one and a half times greater risk for self-harm than boys. Adolescents who have never engaged in self-harm enjoyed the best psychological health. We provide further descriptives of attitudinal components of self-harm behaviour. Exploratory Structural Equation Modeling, which allows cross-loadings of the items, strengthened the original two-factor structure of the second part of the ISAS-HU; an intrapersonal and an interpersonal function factor emerged with good reliability. Among girls intrapersonal functions of self-harm associated with poorer mental health and more maladaptive emotion regulation. Repetitive self-harmers, in comparison with occasional self-harmers, engaged in self-harm mainly because of intrapersonal motives.

Conclusions: ISAS-HU is a psychomterically valid tool which can assess non-suicidal self-injury easily, quick and in its complexity.

Keywords: non-suicidal self-injury; Inventory of Statements About Self-Injury; measurement adaptation; psychometrics; adolescents

A cikk a Creative Commons Attribution 4.0 International License (https://creativecommons. org/licenses/by/4.0/) feltételei szerint publikált Open Access közlemény, melynek szellemében a cikk bármilyen médiumban szabadon felhasználható, megosztható és újraközölhetô, feltéve, hogy az eredeti szerzô és a közlés helye, illetve a CC License linkje és az esetlegesen végrehajtott módosítások feltüntetésre kerülnek. (SID_1) 